\title{
Comment
}

\section{History, Homosexuality, and Political Values: Searching for the Hidden Determinants of Bowers v. Hardwick}

\author{
Anne B. Goldstein $†$
}

On August 3, 1982, Michael Hardwick was arrested in his own bedroom for making love with another consenting adult and charged with sodomy. ${ }^{1}$ Hardwick and his male lover spent ten humiliating hours in jail, but the district attorney decided not to prosecute them. ${ }^{2}$ In response to this experience with Georgia's criminal justice system, Hardwick filed a federal civil rights challenge to the statute that made his private lovemaking a crime, alleging that it violated his "fundamental right of privacy." In considering this case, the various courts ${ }^{3}$ analyzed the issues he raised under the modern cases establishing a constitutional right of privacy. ${ }^{4}$ Writing for a majority of five, Justice White concluded that the constitutional right

\footnotetext{
$\dagger$ Associate Professor of Law, Western New England College School of Law. The author thanks Howard I. Kalodner, Dean, Western New England College School of Law, for reading earlier drafts and for providing institutional support that aided in the completion of this article. She also thanks Gary Buseck, Mary Joe Frug, Molly Geraghty, James Gordon, Cathy Jones, Leora Harpaz, Kathleen Lachance, Michele Dill LaRose, Art Leavens, Stephanie Levin, Bruce Miller, Martha Minow, Dennis Patterson, David A.J. Richards, Barry Stern, Sam Stonefield, Kathleen Sullivan, Samuel Thorne, Donna Uhlmann, and Keith Werhan for their assistance, and, above all, Zipporah B. Wiseman, without whose encouragement and support this would never have been written.

1. GA. Code ANN. $\S 16-6-2$ (a) (1984) provides, "A person commits the offense of sodomy when he performs or submits to any sexual act involving the sex organs of one person and the mouth or anus of another...."

2. Hardwick and his lover were held in a cell with about twelve other men. Jail employees repeatedly joked that they would be sexually assaulted by other inmates. See Affidavit of Michael David Hardwick, dated Sept. 19, 1982 (not filed in court; on file with the author).

3. See 478 U.S. 186 (1986), rev'g Hardwick v. Bowers, 760 F.2d 1202 (11th Cir. 1985).

4. Justice White also rejected Hardwick's argument that his conduct was protected under the Fourth Amendment because it occurred in his own home. 478 U.S. at 195. Justice Stevens' dissent was based upon equal protection analysis, id. at 214-20, also considered in Justice Blackmun's dissent, id. at 202 n.2.
} 
of privacy described by the Court's prior cases did not extend to "homosexual sodomy." Writing for the four dissenters, Justice Blackmun argued that Hardwick's lovemaking was within that private sphere of individual liberty kept largely beyond the reach of the state. ${ }^{6}$

The Court's focus on "constitutional privacy" doctrine obscured two other important determinants of the opinions in Hardwick: the Justices' underlying political philosophies and their understandings of the act for which Hardwick was arrested. ${ }^{2}$ The Justices disagreed about more than just the interpretation of prior cases and their application to new facts. They disagreed about the basic meaning of the terms "privacy" and "homosexuality," and, although they did not frame their dispute in these terms, they disagreed over fundamental political values.

Central to the majority's treatment of the case is its claim that "homosexual sodomy" has always been abhorred. Both Justice White's opinion and Chief Justice Burger's concurrence rely heavily on the asserted antiquity of proscriptions against "homosexual sodomy" to understand Hardwick's conduct and to analyze his constitutional claims. They cite "ancient proscriptions" to demonstrate that the framers could not have intended the Bill of Rights or the Fourteenth Amendment to protect Hardwick's "homosexual sodomy,"B and to support their implicit view that "homosexual sodomy" is sinful and immoral, and hence that it is now, as it always has been, properly punished by the criminal law.

Glose examination of the historical accounts on which Justice White and Chief Justice Burger rely for these assertions reveals that they are certainly misleading, and in some cases inaccurate as well. Even their apparently uncontroversial assumption that lovemaking between persons of the same $\operatorname{sex}^{8}$ has always been seen as fundamentally different from heter-

5. Id. at 191. Chief Justice Burger, and Justices Powell, Rehnquist, and O'Connor, joined Justice White's majority opinion. Burger and Powell filed separate concurring opinions. Burger emphasized what he asserted were the "ancient roots" of the Georgia law. Id. at 196-97 (Burger, C.J., concurring). Powell suggested that the statute's maximum 20-year sentence for a single private, consensual act might be a cruel and unusual punishment under the Eighth Amendment. Id. at 197-98. (Powell, J., concurring).

6. Id. at 203 (Blackmun, J., dissenting). Justices Brennan, Stevens, and Marshall joined Blackmun's dissent.

7. Most commentary on this case either accepts the Justices' characterizations of their handiwork at face value and explores the decision's implications in those terms, or attempts to relitigate the case on a different theory from the one actually employed. See, e.g., Conkle, The Second Death of Substantive Due Process, 62 IND. L.J. 215 (1986-87); Gillerman, Dred Scott Revisited: A Comment on Bowers v. Hardwick, 30 Boston B.J. 4 (Sept./Oct. 1986); Mohr, Mr. Justice Douglas at Sodom: Gays and Privacy, 18 Colum. Hum. RTs. L. Rev. 43 (1986-87); Richards, Constitutional Legitimacy and Constitutional Privacy, 61 N.Y.U. L. REv. 800 (1986); Stoddard, Bowers v. Hardwick: Precedent by Personal Predilection, 54 U. ChI. L. Rev. 648 (1987); The Supreme Court, 1985 Term-Leading Cases, 100 HARv. L. Rev. 100, 210-20 (1986) [hereinafter Leading Cases].

8. 478 U.S. 191-92 (White, J.); id. at 196-97 (Burger, C.J., concurring).

9. This Comment focuses exclusively on historical attitudes toward, and treatment of, sex between men. Because women had different social and biological roles and responsibilities, a corresponding discussion of historical attitudes toward, and treatment of, sex between women is beyond the scope of this Comment, although it merits full treatment elsewhere. 
osexual lovemaking is incorrect: This distinction turns out to be more modern than either the Bill of Rights or the Fourteenth Amendment.

After carefully examining the Justices' historical claims, this Comment examines the interrelations between their differing use of "privacy," understandings of "homosexuality," and political values. The Comment will argue that the political philosophies underlying the majority and dissenting opinions in Hardwick inform the Justices' definitions of "privacy" and interact with their differing understandings of "homosexuality." The majority's understanding of homosexuality as immoral corresponded with its willingness to justify criminal prohibitions by reference to morality. In contrast, the dissenters' understanding of homosexuality as a normal human variation coincided with the importance they attach to preserving individual liberty.

This Comment explores the relationships between the Justices' understandings of homosexuality and their political values by comparing the Hardwick opinions to an earlier dispute over whether consensual lovemaking should be a crime: the celebrated Hart-Devlin debate. The Comment concludes with some thoughts on the probable effects of Hardwick on future constitutional litigation.

\section{The Justices' Doctrinal Disagreements}

Writing for the majority, Justice White announced that the constitutional right of privacy did not protect even private and consensual homosexual sodomy. White narrowly limited the Court's earlier privacy cases to their facts, ${ }^{10}$ and refused to extend them, arguing that substantive due process rights not found in the text of the Constitution, such as the right of privacy, should not represent merely the Justices' own values. ${ }^{11}$ Such rights must either be " 'deeply rooted in this Nation's history and tradition," "12 or " 'implicit in the concept of ordered liberty,' such that 'neither liberty nor justice would exist if [they] were sacrificed." "13 Because Justice White believed that every state that ratified the Bill of Rights and all but five of those that ratified the Fourteenth Amendment proscribed homosexual sodomy, ${ }^{14}$ he perceived any claim that homosexual sodomy involved a "substantive due process" right to be "facetious."15 White concluded that recognizing a fundamental right to "homosexual sodomy" would exceed the Court's institutional limits. ${ }^{16}$ Because Hardwick had no fundamental right to engage in homosexual sodomy, ${ }^{17}$ the Court sought

10. 478 U.S. at 190.

11. Id. at 191 .

12. Id. at 192 (quoting Moore v. City of East Cleveland, 431 U.S. 494, 503 (1977)).

13. Id. at 191-92 (quoting Palko v. Connecticut, 302 U.S. 319, 325-26 (1937)).

14. Id. at $192-93$.

15. Id. at 194 .

16. Id.

17. Id. at 192 . 
merely a rational basis ${ }^{\mathbf{1 8}}$ for Georgia's statute. White's opinion held that the "presumed belief of a majority of the electorate in Georgia that homosexual sodomy is immoral and unacceptable"10 was sufficient justification for the law. Writing separately, Chief Justice Burger emphasized the "ancient roots" of proscriptions against "homosexual sodomy."20

In dissent, Justice Blackmun rejected the majority's framing of the issue. For Blackmun, the case involved not merely a right to perform homosexual sodomy, but "the fundamental interest all individuals have in controlling the nature of their intimate associations with others, ${ }^{, 21}$ or, even more broadly, "the right to be let alone." "22 Blackmun articulated two reasons for framing the issues expansively. First, he thought that because the statute used anatomical rather than gender-based proscriptions, it should not be tested "as applied" to homosexuals alone. Selective enforcement of Georgia's statute might confer standing on a "practicing homosexual," but no enforcement pattern could narrow the language of a statute that made both gender and marital status irrelevant. ${ }^{23}$ Second, Justice Blackmun believed "sexual intimacy" to be "'a sensitive, key relationship of human existence, central to family life, community welfare, and the development of human personality." "24 He thought it as "central a part of an individual's life"25 as the activities already protected by the constitutional right of privacy. Although he would have applied a stricter test, ${ }^{28}$ Blackmun argued that the Georgia law lacked even a rational basis: Georgia had not proved that private, consensual homosexual sodomy caused

18. Under both the equal protection and due process clauses of the Fourteenth Amendment, the Court has calibrated its scrutiny of challenged laws to the interests it perceives to be involved in the case. When no interest justifying greater vigilance appears to be at stake, the Court is deferential to legislative judgments. In these cases it requires only that the law have a "rational basis": a reasonable relationship to a legitimate public purpose based on some conception of the general public good. See L. Tribe, American Constitutional Law 994-96 (1978).

The Court's least deferential review is reserved for cases in which a suspect classification, such as race, has been employed, or where a fundamental right has been impaired. Review in these cases is called "strict scrutiny." It is usually fatal. See id. at 1000-12.

The Court has also used an intermediate level of deference to review laws employing classifications such as gender, see Craig v. Boren, 429 U.S. 190 (1976), or illegitimacy, see Trimble v. Gordon, 430 U.S. 762 (1977).

19. 478 U.S. at 196. Reasoning that "the law is constantly based on morality," the majority was "unpersuaded" "that majority sentiments about the morality of homosexuality should be declared inadequate." Id.

20. Id. at 196-97 (Burger, C.J., concurring).

21. Id. at 206 (Blackmun, J., dissenting).

22. Id. at 199 (Blackmun, J., dissenting) (quoting Olmstead v. United States, 277 U.S. 438, 478

(1928) (Brandeis, J., dissenting)).

23. 478 U.S. at 200-01 (Blackmun, J., dissenting).

24. Id. at 205 (Blackmun, J., dissenting) (quoting Paris Adult Theatre I v. Slaton, 413 U.S. 49, 63 (1973)).

25. 478 U.S. at 204 (Blackmun, J., dissenting).

26. Blackmun would have given the Georgia statute strict scrutiny because " "the basic reasons" " for constitutional protection of individual decisions about the family mandate protection of sexual expression per se. Id. at 204-06 (Blackmun, J., dissenting) (quoting Moore v. City of East Cleveland, 431 U.S. 494, 501 (1977) (plurality opinion)). 
any form of tangible harm. ${ }^{27}$ Blackmun also emphatically rejected the argument that "ancient" notions of immorality insulate sodomy statutes from review. ${ }^{28}$

Justice Stevens' dissent took a different approach. It argued that, because prohibitions against sodomy applied historically to married and unmarried participants, of the same and of different sexes, ${ }^{29}$ the Court's rationale for upholding sodomy statutes must apply just as broadly. Stevens therefore considered whether Georgia could enact a neutral law prohibiting sodomy by all persons without exception, ${ }^{30}$ and, if not, whether it could save the statute from being found unconstitutional by selectively enforcing it against homosexuals. Stevens concluded that neither course was permissible, because the "essential 'liberty" recognized in the Court's prior privacy cases encompassed the right of both married and unmarried heterosexual couples to engage in nonreproductive sexual conduct, and because every citizen has the same subjective interest in such liberty. ${ }^{31}$ Stevens could find no neutral and legitimate interest to support selectively enforcing a generally applicable sodomy law against homosexuals; he thought Georgia's asserted interest amounted to nothing more substantial than "habitual dislike . . . or ignorance." ${ }^{\text {32 }}$ Indeed, Stevens argued that

27. 478 U.S. at $208-09$ \& n.3.

28. Id. at 210 (Blackmun, J. dissenting).

29. Id. at 214-15 \& n.2 (Stevens, J., dissenting).

Because Hardwick's complaint raised no equal protection claim, Stevens was, in effect, redrafting the complaint. Had Hardwick used this theory below, Georgia might have made a better showing on it. Although ingenious arguments have stretched equal protection doctrine to fit homosexual rights, see, e.g., Note, The Constitutional Status of Sexual Orientation: Homosexuality as a Suspect Classification, 98 HARv. L. REv. 1285 (1985) [hereinafter Suspect Classification]; Note, An Argument for the Application of Equal Protection Heightened Scrutiny to Classifications Based on Homosexuality, 57 S. CAL. L. REV. 797 (1984), these arguments have both theoretical and practical defects.

It is difficult to characterize "homosexuality" as a condition so similar to race and sex as to be a protected category without severely narrowing the definition of homosexuality. Human sexuality appears to be polymorphous, not dimorphous. Most adults have some sexual interest in persons of their own gender, and very few have no other sexual interests at all. See A. KINSEY, Sexual BeHAvior IN THE HUMAN MALE 636-56 (1948). If equal protection of "homosexuals" benefited only persons with an exclusive, lifelong, sexual preference for others of their own gender, the category might be analogous to race or sex, but it would not include many of the people who violate Georgia's statute with others of the same gender.

Furthermore, the potential power of equal protection analysis may be, paradoxically, its greatest practical weakness. An argument with less potential, which would be less threatening to those who fear that striking down sodomy laws will transform society beyond recognition, is more likely to win cases. Precisely because "an equal protection analysis seeks to unify the private and the political by protecting gay personhood as a whole . . . [and] could provide a comprehensive doctrinal framework for addressing the problem of gay inequality," Suspect Classification, supra, at 1297, it would be a much larger step to strike down a sodomy law on equal protection grounds than on privacy grounds. Courts have uniformly rejected attempts to legitimize homosexual marriage, for example, a result that would probably follow if homosexuals were held to be entitled to equal protection of the laws. See, e.g., Adams v. Howerton, 673 F.2d 1036 (9th Cir. 1982); Baker v. Nelson, 291 Minn. 310, 191 N.W.2d 185 (1971). But see Watkins v. United States Army, 847 F.2d 1329 (9th Cir.) (Army's discharge of, and refusal to reenlist, soldier for mere status as "homosexual" denies him equal protection.), reh'g en bane granted, 847 F.2d 1362 (9th Cir. 1988).

30. 478 U.S. at 216-18 (Stevens, J., dissenting).

31. Id. at $218-20$.

32. Id. at 219 . 
the statute's language demonstrated that the Georgia electorate did not believe homosexual sodomy to be either more immoral or more unacceptable than heterosexual sodomy. ${ }^{33}$ Similarly, the Georgia prosecutor's failure to prosecute Hardwick, even though Hardwick acknowledged that he intended to continue to engage in the prohibited conduct, showed that the prosecutor did not believe that homosexuals should necessarily be punished for violating the statute. ${ }^{34}$ Stevens concluded that Georgia's failure to "provide the Court with any support for the conclusion that homosexual sodomy, simpliciter, is considered unacceptable conduct in that State"35 deprived the statute of a rational basis.

\section{Competing Conceptions of "Privacy" and "HomoseXuality"}

The doctrinal disputes among the Justices in Hardwick proceeded from more basic differences regarding the meanings of "privacy" and "homosexuality." This Section explores that level of disagreement.

\section{A. "Privacy"}

"Privacy" is an evocative word, but courts have been unable to give it precise meaning. ${ }^{36}$ When Michael Hardwick's lawyers claimed that his arrest violated his "right to privacy," they explicitly compared his desire to be uninterrupted in sexual activity in his own bedroom to the desire of a heterosexual couple to use birth control without interference, or the desire of a woman to terminate an early pregnancy. ${ }^{37}$ The Court therefore faced two basic and related questions: What was the nature of the "pri-

33. Id. (the Georgia electorate's representatives "enacted a law that presumably reflects the belief that all sodomy is immoral and unacceptable") (emphasis in original).

34. Id. at 219-20.

35. Id. at 220 (emphasis in original).

36. A "right of privacy" was first discerned in the Constitution in Griswold v. Connecticut. 381 U.S. 479, 485-86 (1965) (married couples' right to contraception grounded in privacy of marital relationship). Although Griswold cited earlier cases, it used the evocative word "privacy" to justify a new substantive due process right with only tenuous support in the text of the Constitution.

Subsequent cases have found a right of privacy in a variety of circumstances. See, e.g., Zablocki v. Redhail, 434 U.S. 374, 386 (1978) (right to remarry because marriage is "the foundation of the family"); Moore v. City of East Cleveland, 431 U.S. 494, 504 (1977) (right to live in extended family); Planned Parenthood v. Danforth, 428 U.S. 52, 67-72 (1976) (married woman may obtain abortion over husband's objection); Cleveland Bd. of Educ. v. LaFleur, 414 U.S. 632, 639 (1974) (mandatory maternity leave rules in public schools unconstitutional because of "freedom of personal choice in matters of marriage and family life"); Eisenstadt v. Baird, 405 U.S. 438, 442-55 (1972) (right to birth control); Stanley v. Georgia, 394 U.S. 557, 564 (1969) (possession of obscene matter in home protected from "unwanted governmental intrusions").

These many inconsistent applications have led some commentators to conclude that privacy is an irredeemably incoherent concept. E.g., Olsen, The Myth of State Intervention in the Family, 18 J.L. Reform 835, 862 n.73 (1985); of. Note, Roe and Paris: Does Privacy Have A Principle?, 26 Stan. L. REv. 1161, 1163 (1974) (Court's treatment of privacy as "self-explanatory, unitary concept" one of its "major failings").

37. Brief for Respondent at 12, Bowers v. Hardwick, 478 U.S. 186 (1986) (No. 85-140) [hereinafter Respondent's Brief]. 
vate" activities that the Court had protected in past decisions? And what was the nature of the act for which Hardwick had been arrested? If the Court understood Hardwick's sexual act as similar to other activities protected under the "constitutional right of privacy," his challenge should have succeeded. If it saw his sexual act as dissimilar from those earlier protected activities, his claim should have failed..$^{38}$ Yet Justice White's majority opinion did not explicitly address either question. It said only, "we think it evident that none of the rights announced in those cases bears any resemblance to the claimed constitutional right . . . asserted in this case." 30

Justice White's conclusion can be self-evident only to those who share his implicit, unarticulated assumptions about the nature of homosexuality and "homosexual sodomy." Recognizing and evaluating the diverse ways in which the Justices conceptualized homosexuality is therefore crucial to understanding their disagreements over this case. This task does not involve an assessment of judicial attitudes toward a known, objectively existing entity. Rather, the task is to discern the paradigms each Justice used to understand the essential nature of Hardwick's activity on that August morning. Although what Hardwick had done was clear, ${ }^{40}$ evaluating whether an arrest was a constitutionally permissible response required a more profound understanding of his activity than accurate fact-finding alone can provide.

\section{B. Five Conceptions of "Homosexuality"}

The majority opinion is written as if the term "homosexual" solved, rather than confused, the problem of evaluating Hardwick's actions in terms of his constitutional rights. Yet, like "privacy," "homosexuality" lacks an unambiguous, ${ }^{41}$ uncontroversial, meaning. In the Hardwick opin-

38. The litigants' briefs were argued in terms of these two basic questions. Georgia's brief characterized the "common principles of this Court's privacy decisions [as] revolv[ing] around marriage, the family, the home and decisions as to whether through procreation the ancient cycles will begin again and, if so, in what manner the new generation will be brought up." Brief for Petitioner at 25, Bowers v. Hardwick, 478 U.S. 186 (1986) (No. 85-140) [hereinafter Petitioner's Brief]. Georgia contrasted these traditional family concerns with what it called "an activity which for hundreds of years, if not thousands, has been uniformly condemned as immoral." Id. at 19. In response, Hardwick's brief described the right of privacy as protecting "values of intimate association," Respondent's Brief, supra note 37, at 9, and "individual autonomy," id. at 12, and characterized Hardwick's activity as "the consensual intimacies of private adult life," $i d$. at 9.

39. 478 U.S. at 190-91.

40. Exactly what Hardwick did was obvious to the arresting officer and clear to the state court judge. Through a partially closed door, the officer saw Michael Hardwick in his candlelit bedroom "naked on the bed engaged in an act of sodomy [with another man] . . . [t]hat being oral sex. Each of the other had each of the other[']s penis in their mouths." Transcript at 3-4, State v. Hardwick, Atlanta Mun. Ct. proceedings on Sept. 14, 1982. Hardwick's lawyers in federal court obscured the specific facts, however, by consistently using the statutory term "sodomy" to describe them.

41. The term "homosexuality" is lexically ambiguous because it can refer either to desire or to conduct. See, e.g., WEBSTER's New Collegiate Dictionary 544 (1981) ( defining homosexuality as "1: the manifestation of sexual desire toward a member of one's own sex; 2: erotic activity with a member of one's own sex"). Although it may at first appear that all members of the Court focus 
ions one may discern at least five very different conceptions of "homosexuality": that it is (1) immoral, ${ }^{42}$ (2) criminally harmful, (3) a manifestation of illness, (4) an identity, and (5) a normal variation of human sexuality. The first two of these focus primary upon actions, the last three upon desire. $^{43}$

The sources for the Justices' conceptions of homosexuality were equally various. Justice White and Chief Justice Burger relied upon what they claimed were historical conceptions of "homosexual sodomy" that they assumed informed the framers' vision of the Bill of Rights and the Fourteenth Amendment. Claiming to be uninfluenced by their personal preferences, ${ }^{44}$ these Justices also relied on the "presumed belief of a majority of the electorate in Georgia that homosexuality is immoral." 45 By comparing "homosexual sodomy" to other crimes, and relying on other sodomy statutes in effect in 1791 and $1868,{ }^{46}$ Justice White also implied that homosexual sodomy is criminally harmful. ${ }^{47}$ Similarly, Chief Justice Burger's references to "millennia of moral teaching" implied that homosexuality is immoral. ${ }^{48}$ Justice Powell's concern that a long prison sentence for a single private, consensual act of homosexual sodomy might violate the Eighth Amendment proscription against cruel and unusual punishment ${ }^{49}$ may reflect a belief that homosexuality is an illness, or a perception that it is no longer generally regarded as a serious crime. ${ }^{\text {so }}$

Justices Stevens and Blackmun, in contrast, discussed the case on the

exclusively upon conduct, as the statute itself did, closer reading reveals that the dissenters rely analytically upon conceptions of homosexuality as a function of desire, and that the majority opinion exploits the ambiguity.

42. Chief Justice Burger's reference to "Judeo-Christian moral and ethical standards," 478 U.S. at 196 (Burger, C.J., concurring), implied that Hardwick's activity was sinful as well as immoral. However, as Justice Blackmun noted, "[ $t$ ] he legitimacy of secular legislation depends . . . on whether the State can advance some justification for its law beyond its conformity to religious doctrine." Id. at 211 (Blackmun, J., dissenting).

43. See supra note 41.

44. See 478 U.S. at 190 (White, J.) ("case does not require a judgment on whether laws against sodomy . . . are wise or desirable"); id. at 197 (Burger, C.J., concurring) ("This is essentially not a question of personal preferences....").

45. Id. at 196.

46. Id. at 192-94.

47. Id. at $195-96$.

48. Id. at 197 (Burger, C.J., concurring)

49. Id. at 197-98 (Powell, J,, concurring). This issue was raised by neither the parties nor the facts.

50. Although the Court normally treats noncapital sentences as a matter of legislative prerogative, it has disapproved punishing a person solely for being ill. Robinson v. California, 370 U.S. 660 (1962) (narcotics addiction). Justice Powell would also review long sentences for minor crimes. See Carmona v. Ward, 439 U.S. 1091 (1979) (Powell \& Marshall, JJ., dissenting), denying cert. to 576 F.2d 405 (2nd Cir. 1978) (five-year sentence for marijuana distribution not unconstitutional).

Justice Powell did not grapple seriously with the Eighth Amendment issue. Even if a long prison sentence for "a single, private consensual act of sodomy" would be questionable, a life sentence for as few as three such acts seems constitutionally unexceptionable. $C$ f. Rummell v. Estelle, 445 U.S. 263, 274 (1980) (life sentence for recidivism, based on three small thefts, not unconstitutional). But see Solem v. Helm, 463 U.S. 227 (1983) (life imprisonment without parole for recidivism, based on seven minor felonies, unconstitutional). Blackmun's sketch of a possible Eighth Amendment argument is much better crafted. See, 478 U.S. at 202 n.2 (Blackmun, J., dissenting). 
assumption that "homosexuality" is a normal human variation. ${ }^{\text {.1 }}$ Justice Blackmun also linked homosexuality to personality or identity, ${ }^{52}$ relying on the views of "mental health professionals." on the apparent values of the Georgia electorate and prosecutor. ${ }^{54}$ Each of these conceptions, and the Justices' support for them, will be evaluated in turn.

\section{The Majority's Historical Justifications for the Ideas of Homosexu- ality as Immorality, Crime, and Illness}

The majority relied heavily upon history to explain and justify the result in this case. Justice White made three historical assertions: (1) "[s]odomy was . . . forbidden by the laws of the original thirteen States when they ratified the Bill of Rights;" (2) "[i]n 1868, when the Fourteenth Amendment was ratified, all but 5 of the 37 States in the Union had criminal sodomy laws;"se and (3) "[p]roscriptions against that conduct have ancient roots." ${ }^{\prime \prime 7}$ Chief Justice Burger's concurrence forcefully elaborated Justice White's third point. Yet none of these historical statements is sufficiently accurate to guide constitutional interpretation.

\section{a. The Framers' Intentions}

Justice White's and Chief Justice Burger's most important justification for viewing "homosexual" sodomy as immoral was that this view was shared by the framers. ${ }^{58}$ Some commentators argue that attempts to know and follow the framers' intent are necessarily misguided, whatever the

51. See, e.g., 478 U.S. at 218-19 (Stevens, J., dissenting) ("the homosexual and the heterosexual have the same interest in deciding how he will . . . conduct himself in his personal and voluntary associations with his companions"); see also id. at 205 (Blackmun, J., dissenting) ("in a Nation as diverse as ours . . . there may be many 'right' ways of conducting [intimate sexual] relationships").

52. See id. at 202 n.2 (Blackmun, J., dissenting) (homosexuality is not "a matter of deliberate personal election. Homosexual orientation may well form part of the very fiber of an individual's personality.").

53. Id.

54. Id. at 219 (Stevens, J., dissenting) (statute reflects belief that all sodomy is unacceptable; prosecutor no longer enforces statute).

55. Id. at 192 n.5 and accompanying text.

56. Id. at $192-93$.

57. Id. at 192 .

58. In addition to his historical claims, White relied on the Georgia electorate's "presumed belief . . . that homosexual sodomy is immoral and unacceptable." Id. at 196. The factual predicate for this argument was thoroughly discredited by Justices Blackmun and Stevens in dissent. See id. at 200 (Blackmun, J., dissenting); id. at 214 n.2 (Stevens, J., dissenting). Because the Georgia law did not single out homosexual acts for proscription, it is unlikely that the electorate, or its representatives in the legislature, intended the law to be applied to homosexual conduct only. The legislative history suggests instead particular concern with heterosexual sodomy. See id. at 200 \& n.1 (Blackmun, J., dissenting) (statute's "purpose seems to have been to broaden the coverage of the law to reach heterosexual as well as homosexual activity"). Moreover, even Michael Hardwick, who had been caught violating the law and had publicly declared his intention to do so again, was not prosecuted, suggesting that Georgia officials condoned secluded and consensual homosexual lovemaking. See $i d$. at 219-20 (Stevens, J., dissenting). Justice White's majoritarian argument relied, therefore, not upon facts but upon conservative political principles, as will be explored in Section III infra. 
method. ${ }^{59}$ Yet even if the goal of discerning historical attitudes in order to follow the framers' intent is accepted, the majority's depiction of eighteenth- and nineteenth-century views of sodomy is too flawed to guide constitutional interpretation.

In 1791, when the Bill of Rights was adopted, three states' criminal statutes singled out sexual acts between men for special condemnation. ${ }^{60}$ Eight of the other states' statutes ${ }^{81}$ proscribed "buggery"

59. Even were Justice White's and Chief Justice Burger's historical claims absolutely correct, it would be passible to argue that they cast little light on "the framers' intentions," or that the framers' intentions ought not to be of controlling weight in constitutional interpretation. See, e.g., Bickel, The Original Understanding and the Segregation Decision, 69 HARv. L. REv. 1 (1955); Ely, Constitutional Interpretivism: Its Allure and Impossibility, 53 IND. L.J. 399 (1978); Grey, Do We Have an Unwritten Constitution?, 27 STAN. L. REv. 703 (1975); Sandalow, Constitutional Interpretation, 79 Mich. L. Rev. 1033 (1981); Sofford, The Blinding Light: The Uses of History in Constitutional Interpretation, 31 U. CHI. L. REv. 502 (1964). But see R. BERGER, GoveRNMENT BY JUDICIARY 363-72 (1977).

It is also possible to argue that the issue of how to interpret the Constitution ought not to be framed in this way, because neither the originalist nor the non-originalist position is a coherent one. See Brest, The Fundamental Rights Controversy: The Essential Contradictions of Normative Constitutional Scholarship, 90 YALE L.J. 1063 (1981). However, a general discussion of constitutional interpretation is beyond the scope of this Comment.

I do not agree with Justice White's and Chief Justice Burger's implicit assumptions that the framers' intentions are determinate and knowable, and that the Court's role is to discern and follow those intentions. However, I think that when the Court uses statements about the past to reach a result in a case, the truth or falsity of those statements is worth examining.

60. These states were Connecticut, Massachusetts, and New Hampshire. See The General Laws and Liberties of the Connecticut Colonie, 1672, reprinted in The EARLIEST LAwS OF THE NEw Haven and ConNecticut Colonies 1639-1673, at 83 (fascimile ed. 1977) ("If any man lyeth with Man-kind, as he lieth with womankind . . . ."); An Act Against Sodomy, 1785, reprinted in The First Laws of the Commonwealth of Massachusetts 250-51 (fascimile ed. 1981) ("That if any man shall lay with mankind as he layeth with a woman . . . "); An Act of the Punishment of Certain Crimes, 1791, reprinted in 5 LAws of New HAMPSHIRE 597 (H. Metcalf ed. 1916) ("That if any man shall carnally lie with a Man as a Man carnally lieth with a Woman . . . ."). The language of these acts is drawn from Leviticus 18:22 (King James) ("Thou shalt not lie with mankind, as with womankind.").

61. These states were Delaware, New York, North Carolina, Pennsylvania, Rhode Island, South Carolina, New Jersey and Virginia. See An Act for the advancement of Justice, and more certain administration thereto, 1719 , reprinted in THE FiRST LAws of THE STATE of Delaware pt. 1, at 67 (facsimile ed. 1981) ("That if any person or persons shall commit sodomy, or buggery . . ."); 2 LAwS OF THE STATE OF NEW YoRK 1sT-24TH Assemblies 1777-1802, ch. 21, at 391 (Albany, 1886) ("That the detestable and abominable vice of buggery, committed with mankind or beast, shall be from henceforth adjudged felony ...."); 13 Statutes at Large of Pennsylvania from 1682-1801, at 511 (1906) (1790 statute proscribing "sodomy or buggery"); An Act for Punishing Griminal Offenses, 1662, reprinted in The Earlest Acts and Laws of THE Colony of Rhode Island and Providence Plantations 1647-1719, at 142 (facsimile ed. 1977) ("the Detestable and Abominable Crimes of Sodomy, or Buggery"); An Act to put in force in this Province the several statutes of the Kingdom of England or South-Britain therein particulary mentioned, 1712, reprinted in The First I.aws of The State of South Carolina pt. 1, at 25, 49 (facsimile ed. 1981) ("the detestable and abominable Vice of Buggery committed with Mankind or Beast"); An Act for the Punishment of the Vice of Buggery, ch. 27, in A Collection of the Statutes of the Parliament of England in Force in the State of North Garolina 314 (1792) ("said vice of Buggery").

The New Jersey Constitution of 1776 provided that English statutes in force prior to the revolution would continue to be law in the state, see E. BROWN, BRITISH STATUTES IN AMERICAN LAW 1776-1836, at 76 (1964). New Jersey repealed all English statutes eight years after the Bill of Rights was ratified. Id. at 82 . Virginia repealed its ordinance adopting all English statutes in 1792. Id. at $113,124$.

62. These statutes borrowed the term "buggery" from the first secular criminal proscription of 
without reference to the gender of the participants. Finally, in one state,

such conduct in England, $25 \mathrm{Hen}$. VIII ch. 6 (1553) (referring to "the detestable and abominable vice of buggery committed with mankind or beast"), which was reenacted by 5 Eliz. ch. 17 (1562). "Buggery" denotes acts which today seem too dissimilar to be named with a single term: anal intercourse between two men, see Stafford's Case, 12 Co. Rep. 36, 37, 77 Eng. Rep. 1318 (1607) (requiring "penetration and emission of seed" for the offense), or between a man and a woman, see $\mathrm{R}$. v. Wiseman, Fortes. 91, 92-93, 92 Eng. Rep. 774, 774 (1716), (buggery with a woman "is a crime exactly of the same nature, as well as it is the same action, as if committed upon a male"), and any sexual penetration between a human being and an animal, see E. CoKE, ThE THIRD PART of THE INSTITUTES OF THE LAWS OF ENGLAND, 58, 59 (London 1644) ("there must be penetratio, that is, res in $r e$, either with mankind, or with beast"). Most of the English and American treatises in use when the Bill of Rights and the Fourteenth Amendment were being written rely on these three sources. See, e.g., J. Bacon, A New Abridgement of the LAw *325-26 (Philadelphia 1811) (citing Coke and Wiseman); 2 J. Chitty, A Practical Treatise on Criminal Law *48-51 (New York 1847) (citing Coke and Wiseman); Conductor Generalis 66 (New York, 1788) (widely-used justice of the peace manual, relying on Coke); J. DAvis, ThE OFFICE AND AUTHORITY OF A JuSTICE OF THE Peace 75 (Newbern 1774) (same); 1 E. East, Pleas of the Crown 480 (London 1803) (citing Coke); J. Giles, A New-Law Dictionary (3d ed. 1736) (citing Coke); W. Hening, The New Virginia Justice 93 (Richmond 1795) (justice of peace manual; citing Coke); W. Russell, A Treatise on Crimes and Misdemeanors *814-15 (Boston 1824) (citing Coke and Wiseman); W. Simpson, The Practical Justice of the Peace 58 (Charlestown 1761) (justice of peace manual; citing Coke); R. Starke, The Office and Authortry of a Justice of the Peace 61 (Williamsburg 1774) (same).

Coke's explication that "Buggery is . . . committed by carnall [sic] knowledge against the ordinance of the Creator and order of nature, by mankind with mankind, or with brute beast, or by womankind with bruite [sic] beast," The THIRD PART of THE InSTITUTES OF THE LAwS OF ENGLAND 58 (London 1644), might imply that a man and woman together could not commit the crime. Although this interpretation was rejected in R. v. Wiseman, Fortes. 91, 92 Eng. Rep. 774 (1716), at least one carlier source disagrees. See M. DAlTon, Countrey Justice 276 (London 1630) (justice of peace manual; "haec per confusionem sexuum, sc. home ove home, feme ove feme," citing the Bible). But see J. GiLES, supra (3d ed. 1736) ("carnalis copula contra Naturam \& haec vel per confusionem specierum, sc. a man or woman with a brute beast, vel. sexuum, a man with a man or a man with a woman") (emphasis added).

63. The term "sodomy" was used less frequently than "buggery." In English and American legal sources of the seventeenth, eighteenth, and nineteenth centuries, "sodomy" had no definite meaning. It was sometimes a synonym for buggery. See, e.g., R. v. Wiseman, Fortes. 91, 95, 92 Eng. Rep. 774, 776 (1716) ("Sodomy is the genus, rem veneream habere in ano with a man is only a species, and with a woman is another species, and so with a boy or girl, is another species, and with a beast another species."); J. BACON, supra note 62 ("Sodomy"; "Sodomy . . . is an unnatural copulation between two human creatures, or between a human and a brute creature."); J. Giles, supra note 62 ("Buggery, or sodomy, . . . . is defined to be . . . a man or woman with a brute beast, [or] a man with a man or a man with a woman," citing Coke). Sometimes "sodomy" had narrower connotations, see, e.g., Stafford's Case, 12 Co. Rep. 36, 37, 77 Eng. Rep. 1318 (1607) (restricted to human beings: "sodomy is with mankind"); R. DEsty, A Compendum of AMERICan CRIMINal Law 143 § 60(a) (1887) (sodomy is anal intercourse: "sexual connection per anum, with mankind or beast") (emphasis in original). 
no statutory proscription against sodomy may have existed in $1791,{ }^{04}$ and in one state the historical evidence is unclear. ${ }^{65}$

By 1868, when the Fourteenth Amendment was ratified, no additional states had singled out sexual acts between men for special prohibition. ${ }^{66}$ Many states' statutes had been bowdlerized, however, and now prohibited "the crime against nature" instead of "sodomy" or "buggery." phrase applied to acts of anal intercourse between men and women as well as between two men. ${ }^{68}$ Courts in at least seven of the thirty-two

64. This was Maryland. Justice White asserted that Maryland's inhabitants were entitled to English common law, including the "common law" crime of "sodomy," 478 U.S. at 192 n.5, but he may have been incorrect. In English jurisprudence, sodomy was considered a statutory rather than a common law crime. See $4 \mathrm{~W}$. Blackstone, CommentaRies *215-16. Thus, merely receiving the common law was inadequate for Maryland to have adopted the English criminal proscription against sodomy; Maryland would have had to adopt $25 \mathrm{Hen}$. VIII ch.6 (1533) (discussed supra note 62).

Maryland's 1776 Declaration of Rights gave its inhabitants "the benefit of such of the English statutes, as existed at the time of their first emigration, and which, by experience, have been found applicable to their local and other circumstances . . . Declaration of Rights, 1776, reprinted in 3 Sources and Documents of United States Constrrutions 372 (W. Swindler ed. 1975). The English buggery statute does not appear in the collection of English laws in force in Maryland compiled by William Kilty under a 1794 directive from the Maryland legislature. See A ColLecrion of the British Statutes in Force in Maryland, according to the Report Thereof Made to the General Assembly by the Late Chancellor Kil.ty (1870); see also S. Sioussat, The ENGlish STATUTES IN MARYLAND 41 (1903) (Kilty's compilation was accepted as authority on status of English statutes in state law); Steiner, The Adoption of English Law in Maryland, 8 Yale L.J. 353, 359-60 (1898-99) (Kilty's compilation was " 'received and respected' by the courts 'as the repository' of English Statutes in force in Maryland," although it was never formally adopted by the legislature.) (citation omitted).

65. This is Georgia. Justice White also asserted that the English "common law" crime of "sodomy" was in effect in Georgia, 478 U.S. at 192 n.5.

Georgia adopted those "common laws of England, and such of the statute laws as were usually in force" in 1784. An Act for reviving and enforcing certain laws therein mentioned, 1784, reprinted in R. Watkins, Drgest of THE LAwS of Georgra 289 (Philadelphia 1800). In 1826, the Georgia legislature formally adopted a list of English laws in force in Georgia, compiled by William Schley. See W. Schley, A Digest of the English Statutes in Force in the State of Georgia vii (Philadelphia 1826). This list did not include the English buggery statute. See id. Thus, it appears that no proscription against buggery was "in force" at the time the Bill of Rights was adopted. It should be noted, however, that in 1817 Georgia adopted a statute proscribing "sodomy and bestiality" as part of a comprehensive penal code. See A Digest of THE LAwS OF THE STATE of GeORGia 350 (Milledgeville 1822). Moreover, in Savannah, Georgia, on March 25, 1734, two Lutheran pastors reported in a German-language diary that on that day there was an "execution of judgement" against a man who was to receive "three-hundred lashes under the gallows" after being "accused and convicted of sodomy and inciting others." J. Katz, Gay/Lesbian Almanac 133 \& n.67 (1983).

66. Indeed, by 1868, Connecticut had a law arguably applicable to acts between men and women as well as between two men. Conn. Gen. Stat. tit. 122, ch. 7, §124 (1866) ("Every person, who shall have carnal knowledge of any man, against the order of nature, shall be punished. . . (emphasis added). See 2 Digest of THE Laws of the State of Connecticut 342, 744 (New Haven, 1823) (treatise by "the late Chief Justice of the State" explains "sodomy" as "carnal knowledge committed against the order of nature by man with man or in the same unnatural manner with woman," and gives a form of indictment modeled on $R$. $v$. Wiseman, supra note 62.)

67. The phrase comes from Blackstone's Commentaries, where it is in turn defined by reference to the English buggery statute. See $4 \mathrm{~W}$. Blackstone, Commentaries *215 ("the infamous crime against nature"); id. at *216 ("25 Hen. VIII ch. 6 revived and confirmed by 5 Eliz. ch. 17").

68. E.g., Dr.l. Code ANN. tit. 20, ch. 131, § 7 (1852); Mass. Gen. L. ch. 165, § 18 (1860); N.C. Rev. Code ch. 34, § 6 (1854); Or. Organic and Gen. Laws, 1845-64, ch. 48, § 639; TenN. CODE, pt. 4 , tit. 1 , ch. 8 , art. $1, \S 4843$ (1858).

69. See, e.g., J. CHITTY, supra note 62 , at 49 (sodomy defined as "anal intercourse between human beings."); R. DEsTy, supra note 63, at 143, \& 60(a) (1887) ("it is sexual connection per anum, with mankind or beast, but not with fowl." (emphasis in original) (footnotes omitted)); J. 
states Justice White found to have "criminal sodomy statutes in effect in 1868 ,"70 explicitly held that these statutes did not apply to oral-genital contact. $^{71}$ Some treatise writers explicitly included sodomy in marriage within the statutory proscription. ${ }^{72}$

Thus, the evidence does not support Justice White's conclusion that the framers could not have intended the Constitution to "extend a fundamental right to homosexuals to engage in acts of consensual sodomy." ican sodomy laws in force when the Bill of Rights and the Fourteenth Amendment were ratified applied to acts performed by men with women as well as with one another. Only three of the thirteen original states singled out sex acts between men for proscription; the others prohibited "sodomy" and "buggery," terms denoting sex acts between men and women as well as between two men. Moreover, in both 1791 and 1868

MAy, The Law of Crimes 223, § 210 (1881) ("Sodomy . . . is the unnatural carnal copulation of one human being with another, or with a beast. . . . To constitute the offense between human beings, the act must be per anum.") (footnote omitted); W. Russell, supra note 62, *815 ("man with man; or in the same unnatural manner with woman"); see also 478 U.S. at 215 n.4 (Stevens, J., dissenting) (citing sources).

Georgia's modern statutory definition of "sodomy" may mislead the uninitiated to suppose that the word has always denoted oral-genital practices as well as anal intercourse. In fact, the meaning of sodomy has varied over the ages, connoting "in various times and places everything from ordinary heterosexual intercourse in atypical position to oral sexual contact with animals." J. BoswelL, Christianity, Social Tolerance and Homosexuality 93 n.2 (1981); see also V. Bullough, SeXual Variance in Society and History 380-84 (1976).

70. 478 U.S. at 193 n.6.

71. See People v. Boyle, 116 Cal. 658, 48 P. 800 (1897) ("infamous crime against nature" does not proscribe oral-genital conduct with child); Riley v. Garrett, 219 Ga. 345, 133 S.E.2d 367 (1963) (sodomy statute inapplicable to heterosexual cunnilingus); Commonwealth v. Poindexter, $133 \mathrm{Ky}$. 720,118 S.W. 943 (1909) ("crime of sodomy or buggery" does not proscribe fellatio); People v. Schmitt, 275 Mich. 575, 267 N.W. 741 (1936) ("abominable and detestable crime against nature" does not proscribe fellatio); State v. Morrison, 25 N.J. Super. 534, 537, 96 A.2d 723, 725 (Essex County $\mathrm{Ct}$. 1953) ("There is almost complete accord among text-writers that at common law commission of the crime required penetration per anum, and that penetration per os did not constitute the offense."); Munoz v. State, 103 Tex. Crim. 439, 440, 281 S.W. 857, 857 (1926) ("[H]owever vile and detestable [fellatio] may have been, it does not come within the definition of 'sodomy' as known to the common law and adopted by legislative enactment in our State."); Wise v. Commonwealth, $135 \mathrm{Va}$. 757, 115 S.E. 508 (1923) ("buggery" does not proscribe fellatio).

Georgia's own statute was not applied to fellatio until this century. See Herring v. State, $119 \mathrm{Ga}$. $709,720,46$ S.E. 876,882 (1904) (applying statute to fellatio for first time).

These cases and the treatise writers cited supra note 69 appear influenced by a 1817 case decided in England, which interpreted the 1533 English buggery statute, $25 \mathrm{Hen}$. VIII ch. 6, not to proscribe fellatio. R. v. Jacobs, Russ. \& Ry. 331, 168 Eng. Rep. 830 (1817) (act of oral sex forced by defendant on boy did not constitute sodomy).

72. See J. May, The Law of Crimes $\$ 203$ (2d ed. 1893) ("Sodomy . . . may be committed . . . by a man with a woman-his wife, in which case, if she consent, she is an accomplice.").

In the $1800 \mathrm{~s}$, medical authorities believed that inheritable physical infirmities would result from masturbation, see V. Bullough \& B. Bullough, Sin, Sickness and Sanity: A History of SeXual ATtitudes 55-73, 201-09 (1977); P. Conrad \& J. Schneider, Deviance and MedicalizaTION: FROM BADNESS to SICKNESS 180-85 (1980), and defined as masturbation "every kind of sexual activity that did not lead to procreation." V. Bullough \& B. Bullough, supra, at 62. It seems likely, therefore, that if any distinction had then been made between "homosexual sodomy" and sodomy in marriage, the latter would have been considered much more heinous because sodomy in marriage was believed to cause stillbirths or to make the offspring of the marriage sick, weak, and deformed.

73. 478 U.S. at 192. 
statutes proscribing "sodomy," "buggery," and the "crime against nature," were interpreted to proscribe anal intercourse only-not fellatio, the act for which Hardwick was arrested. ${ }^{74}$

\section{b. "Ancient" Prohibitions and the Concept of "Homosexuality"}

The majority bolstered its inferences about the framers' intentions with the claim that "[p]roscriptions against [homosexual sodomy] have ancient roots."75 Although literally true, the statement is misleading in two ways. First, it oversimplifies and distorts a complex historical record; second, it misuses the relatively modern concept of "homosexuality" to depict the past.

Over the course of Western history, sexual practices between men, like other sexual practices, have been tolerated as well as condemned. In class-

74. Oral-genital practices were not punished as crimes in Britain until 1885, and probably were not in this country until a decade later.

The 1553 English buggery statute did not proscribe fellatio. See R. v. Jacobs, Russ, \& Ry. 331, 168 Eng. Rep. 830 (1817). In 1885, the British Parliament passed a statute making "gross indecency" a misdemeanor, punishable by imprisonment for "any term not exceeding two years with or without hard labour." Criminal Law Amendment Act, 1885, 48 \& 49 Vict. c. 59; see also V. Bullough, SeXual Variance in SOcIeTY aND History 570-72 (legislative history). This statute has been applied to, among other practices, oral-genital contact between men. Its earliest well-publicized use was in the prosecution of Oscar Wilde. See V. Bullough, id, 573-75; T. HumpHreYs, A Book of TRIALS 33-43 (1953).

Perhaps the notoriety of Oscar Wilde's 1895 arrest, trial, and conviction for gross indecency affected judicial attitudes and beliefs on this side of the Atlantic. Beginning in 1897, American courts did sometimes apply proscriptions of "sodomy" or the "crime against nature" against oral-genital practices, but they acknowledged that this interpretation changed the common law. Courts in at least fourteen of the thirty-two states with "criminal sodomy statutes in effect in 1868," 478 U.S. at 193 n. 6 , acknowledged that by applying the state's statute to oral-genital contact they were aitering the common law meaning of sodomy; the earliest such decision was rendered in 1897. See Honselman v. People, 168 Ill. 172, 175, 48 N.E. 304, 305 (1897)("the legislature included in the crime against nature other forms of the offense than sodomy or buggery"; fellatio); see also, Woods v. State, 10 Ala. App. 96, 64 So. 508 (1914)(fellatio punished as "a crime against nature"); State v. Maida, 29 Del. (6 Boyce) 40, 96 A. 207 (1915); Ephraim v. State, 82 Fla. 93, 89 So. 344 (1921) (fellatio punished as "abominable and detestable crime against nature"); State v. Vicknair, 52 La. Ann. 1921, 28 So. 274 (1900)(1896 statutory amendment expanded common law "detestable and abominable crime against nature" to include fellatio); State v. Cyr, 135 Me. 513, 514, 198 A. 743, 743 (1938)(citing "weight of recent authority" for interpreting "crime against nature" to include fellatio); Commonwealth v. Dill, 160 Mass. 536, 537, 36 N.E. 472, 473 (1894)(1887 prohibition of "unnatural and lascivious acts" intended "to include and punish any mode of unnatural copulation not coming within the definition of sodomy as uaually understood"); State v. Hill, 179 Miss. 732, 176 So. 719 (1937)("infamous crime against nature" enlarged common law sodomy to include cunnilingus); State v. Katz, 266 Mo. 493, 181 S.W. 425 (1916) (proscription of "abominable and detestable crime against nature, committed with mankind or with beast, with the sexual organs or with the mouth" expands common law sodomy to include fellatio); In re Benites, 37 Nev, 145, 140 P. 436 (1914)(fellatio punished as "infamous crime against nature"); State v. Fenner, 166 N.C. 247, 80 S.E. 970 (1914)("crime against nature" of broader import than sodomy; applied to fellatio); State v. Start, 65 Or. 178, 132 P. 512 (1913)(fellatio punished as "crime against nature") (reversed on other grounds); State v. Milne, 95 R.I. 315, 187 A.2d 136 (1962)(fellatio punished as "abominable and detestable crime against nature"); Fisher v. State, 197 Tenn. 594, 277 S.W.2d 340 (1954)("penetration per os" prohibited as "crime against nature"). See generally Spence, The Law of Crime Against Nature, 32 N.C.L. REv. 312, 312-18 (1954); cf. Wainwright v. Stone, 414 U.S. 21 (1973)(statutory phrase "abominable and detestable crime against nature" not vague); Rose v. Locke, 423 U.S. 48 (1975)("crime against nature" forseeable proscribes cunnilingus).

75. 478 U.S. at 192. 
ical Greece and Rome, sexual practices between men were not uniformly condemned, ${ }^{76}$ and some were widely accepted; ${ }^{77}$ under Roman rule, even marriage between men was possible until at least 342 A.D. ${ }^{78}$ Sexual acts between men were also openly tolerated by both church and state during the early Middle Ages, ${ }^{79}$ and among the male social elite in eighteenthcentury France. ${ }^{80}$ By ignoring ancient tolerance to focus selectively on ancient proscriptions, the majority distorted the historical record. This distortion enabled the majority to present its choice of proscription over tolerance as if it were merely fidelity to "ancient roots," laws in force "throughout the history of Western Givilization."

The majority's use of the concept of homosexuality is flawed as well. All of the Justices seem to have assumed that "homosexuality" has been an invariant reality, outside of history. In fact, however, like most ways of describing aspects of the human condition, "homosexuality" is a cultural and historical artifact. No attitude toward "homosexuals" or "homosexuality" can really be identified before the mid-nineteenth century because the concept did not exist until then. Before the late 1800 s, sexuality - whether tolerated or condemned-was something a person did, not what he or she was. ${ }^{83}$ Although both the behavior and the desires we now

76. Chief Justice Burger's assertion that "[h]omosexual sodomy was a capital crime under Roman law," 478 U.S. at 196 (citing Theodosian and Justinian Codes), is somewhat misleading. Both the Theodosian and the Justinian Codes were enacted after the classical period, in A.D. 390 and 533, respectively, and the Theodosian Code imposed the death penalty only for forcing or selling males into prostitution. See J. BoswELL, supra note 69, at 123-24. Thus, "[n]ot until [A.D.] 533 did any part of the [Roman] Empire see legislation flatly outlawing homosexual behavior, even though Christianity had been the state religion for more than two centuries." Id. at 171 . Sexual acts between men were not prohibited by secular law in the west until A.D. 533, when they became punishable by death, the same penalty imposed for adultery. Id.

77. Among the Grecks, for example, there were many shadings and variations of acceptance and disapproval of sex between men, depending upon such factors as the city, social class, precise historical time, relative ages, and the "manliness" or "effeminacy" of the participants. See generally K.J. DoVER, GREEK HOMOSEXUALITY (1978). There was a prejudice against freeborn, adult men taking the "passive" role in any sexual relationship, either with a woman or with another man. See, e.g., M. Foucault, The Use of Pleasure: Volume Two of The History of Sexualtiy 216-25 (R. Hurley trans. 1985).

78. See J. Boswell, supra note 69 , at 59,73 .

79. Id. at 293-95. Then, "[b]etween 1250 and 1300, homosexual activity passed from being completely legal in most of Europe to incurring the death penalty in all but a few contemporary compilations." Id. at 293. Until 1300, church law paralleled secular law, condemning and punishing homosexual activity only to the extent other non-marital sexual activity-including non-coital sex within marriage-was condemned and punished. Id. at 269-332.

80. See Delon, The Priest, The Philosopher, and Homosexuality in Enlightenment France, 9 Eighteenth Century Life 122-23 (1985).

81. 478 U.S. at 192.

82. Id. at 196 (Burger, C.J., concurring).

83. See Gilbert, Conceptions of Homosexuality and Sodomy in Western History, $6 \mathrm{~J}$. Homosexuality 57, 61 (1981), reprinted in Historical Perspectives on Homosexuality (S. Licata \& R. Petersen ed. 1981) (homosexuals not conceptualized as identifiable segment of society until late nineteenth century); Veyne, Homosexuality in Ancient Rome, in WESTERN SEXuality: PRACTICE AND Precept in PAst ANd Present Times 26 (P. Aries \& A. Bejin ed. 1985) ("It is incorrect to say that the ancients took an indulgent view of homosexuality. The truth is that they did not see it as a separate problem ...."). 
call "homosexual" existed in earlier eras, ${ }^{84}$ our currently common assumption that persons who make love with others of their own sex are fundamentally different from the rest of humanity is only about one hundred years old..$^{85}$

Even the word "homosexual" is new. It was coined in the nineteenth century to express the new idea that a person's immanent and essential nature is revealed by the gender of his desired sex partner. ${ }^{86}$ The concept emerged around the time that sexuality began to seem a proper object of medical, as distinguished from clerical or judicial, concern. Before the invention of "homosexuality," sexual touchings between men were determined to be licit or illicit according to criteria that applied equally to heterosexual practices, such as the parts of the body involved, ${ }^{87}$ the relative status of the parties, and whether the sexual drama conformed to sex role stereotypes. ${ }^{88}$ Although illicit sexual acts were seen as sinful, immoral, criminal, or all three, before the 1870 s illicit sexual acts between men were not seen as fundamentally different from, or necessarily worse than, illicit acts between a man and a woman. ${ }^{89}$

Thus, by referring to "homosexual sodomy" in ancient times, in 1791,

84. See Amicus Curiae Brief of the American Psychological Association and American Public Health Association, Bowers v. Hardwick at 10-11, 478 U.S. 186 (1986) (No. 85-140) [hercinafter Amicus Brief] ("[H]istorical evidence reveals that homosexuality . . . [has] been common in western societies since before the Christian era. Homosexuality has been ubiquitous, whether a particular culture admired, ignored or vilified it.") (footnotes omitted).

85. Michel Foucault gave 1870 as the "convenient date" of the concept's birth. See M. FouCault, The History of Sexualtyy, Volume One: An Introduction 43 (R. Hurley trans. 1978).

This surprising notion that "homosexuality" is a fairly modern way of conceptualizing human behavior and interests has come to be accepted by scholars only within the past ten or fifteen years. See Gilbert, supra note 83, at 61; Rousseau, The Pursuit of Homosexuality in the Eighteenth Century: "Utterly Confused Category" and/or Rich Repository?, 9 ErghteENTH CENTURY LifE 132, 162 n.1 (1985).

86. The nineteenth-century innovation consisted of identifying people by the gender of their sexual object choice:

The nineteenth-century homosexual became a personage, a past, a case history, and a childhood, in addition to being a type of life, a life form, and a morphology, with an indiscreet anatomy and possibly a mysterious physiology. Nothing that went into his total composition was unaffected by his sexuality. It was everywhere present in him: at the root of all his actions because it was their insidious and indefinitely active principle; written immodestly on his face and body because it was a secret that always gave itself away. It was consubstantial with him, less as a habitual sin than as a singular nature.

M. Foucault, supra note 85 , at 43.

87. See J. Boswell, supra note 69, at 182-83; and Flandrin, Sex in Married Life in the Early Middle Ages: the Church's teaching and behavioral reality, in WESTERN SEXuALITY, supra note 83, at 120-21 (anal intercourse, fellatio, and cunnilingus all forbidden to married couples in fifteenth century Christian Europe).

88. See M. Foucauli, supra note 77, at 220 (in classical Greece, acceptable sexuality involved domination of "feminine" partner by "masculine" partner); M. Foucault, The Care of the Self: Volume Three of the History of Sexuality 189-90 (R. Hurley trans. 1986) (in Republican Rome, acceptable sexual partner for a male citizen was a woman or a slave); Flandrin, supra note 87, at 120-21 (discussing acceptable positions for intercourse, and rationales therefor, in fifteenth century Christian Europe).

89. The Georgia statute under which Hardwick was arrested reflects this tradition. It does not distinguish between heterosexual and homosexual acts, but instead prohibits particular, anatomically defined, touchings. See supra note 1 (quoting statute's language). 
and even in 1868, White and Burger were inserting their modern understanding of "homosexuality" anachronistically into systems of values organized on other principles, obscuring the relative novelty of the distinction between "homosexuality" and "heterosexuality" with a myth about its antiquity. Moreover, their anachronistic myth distorted the meaning "homosexuality" had for its nineteenth-century inventors. Nineteenthcentury medical theories about "homosexuality" seem to have developed out of contemporaneous theories about the dangers of sexual arousal and satisfaction, and the debilitating effects of masturbation. ${ }^{20}$ The concept was introduced as a medical category, ${ }^{91}$ and was intended to rebut the idea that sex between men could be either sinful or criminal. ${ }^{.2}$ "Homosexuality," in the nineteenth century, implied that sexual inclinations toward a person of one's own sex are beyond one's control (at least without professional treatment). ${ }^{83}$ Using the nineteenth-century medical category of homosexuality to justify the law's treatment of sex between men as criminal thus precisely inverts the term's historical significance.

\section{The Dissenters' Justifications for the Idea of Homosexuality as Normal Variation and Identity}

In order to decide this case, the Court had to choose among inconsistent paradigms for "homosexuality." The conceptions relied on by the majority do not exhaust current thinking on this issue. Alternate conceptions adopted by the dissenters treat homosexuality as an identity and as a biologically normal variation of human sexuality. ${ }^{94}$ The dissenters justified these views by reference to modern scientific consensus and to one tendency among contemporary values; ${ }^{95}$ Justice Stevens, ironically but correctly, ${ }^{98}$ also relied on the beliefs of the Georgia legislature, electorate, and

90. See V. Bullough \& B. Bullough, supra note 72, at 55-73, 201-09; P. Conrad \& J. SCHNEIDER, supra note 72, at 180-85 (1980).

91. The word was coined by a physician in 1869 to denote:

a sexual bondage which renders [men] psychically incapable-even with the best intention-of normal erection. This urge creates in advance a direct horror of the opposite [sex], and the victim of this passion finds it impossible to suppress the feelings which individuals of his own sex exercise on him.

P. Conrad \& J. Schneider, supra note 72, at 183 (1980).

92. See id. at $182-85$.

93. See id. at 181, 183-84; M. Fouchult, supra note 85, at 116-20.

For discussions of the various medical theories of homosexual etiology and the treatment modalities they engendered, see the bibliography appended to W. Masters \& V. JoHnson, HomoseXuaLITY In Perspective 413-36 (1979), and for a more anecdotal perspective, see J. KaTz, Gay AMERICAN HistoRY 129-207 (1976).

94. 478 U.S. 202 n.2 (Blackmun, J., dissenting).

95. Id. at 202 n.2, 204-06, 210-211 (Blackmun, J., dissenting).

96. In recent years Georgia courts have consistently disregarded participants' genders when interpreting laws regulating sexual behavior. See, e.g., Owens v. Owens, 247 Ga. 139, 140, 274 S.E.2d 484, 485-86 (1981) ("both extramarital homosexual, as well as heterosexual, relations constitute adultery"); Allen v. State, $170 \mathrm{Ga}$. App. 96, 316 S.E.2d 500 (1984) (man's offer to perform anal intercourse with another man violates prohibition against performing "sexual intercourse for money"). 
prosecutors, as revealed by the language of the statute and the state's pattern of non-enforcement. ${ }^{97}$

Like the ideas of "immorality," "crime," and "illness" discussed above, each of the dissenters' ideas reflects a particular world view. The idea of "homosexuality as identity" seems to have been invented for selfdescription. In a development related to, and roughly contemporaneous with, the invention of "homosexuality" as a medical category, some lay people adapted the idea to understand themselves and to seek societal tolerance. ${ }^{98}$ These self-described homosexuals did not always accept the medical assumption that their condition was an illness (or "perversion") requiring treatment, but they did agree that the gender of a person's desired sex partner revealed something essential about his nature.9

In the 1950s, the nineteenth-century conception of homosexuality as an illness or identity began to be challenged by a new concept: "homosexuality as normal variation." This idea combined the pre-nineteenth-century assumption that a person's sexuality should be evaluated without considering the gender of his object choice with the twentieth-century notion that sexual expression is good and sexual repression, bad. ${ }^{100}$ The idea that homosexuality is a normal manifestation of human sexuality has gradually achieved scientific acceptance; the American Psychiatric Association formally adopted this position in $1973 .{ }^{101}$ The idea that homosexuality

97. 478 U.S. at 219-20 (Stevens, J., dissenting).

98. Several theories have been advanced to explain the late-19th century emergence of the idea that the "homosexual" was a distinct type of human being. Michel Foucault has theorized that sexuality was "medicalized" for the aggrandizement of doctors and to increase social control. See M. FoucAuLT, supra note 85 , at $43,47,103-114,123$. This may explain the emergence of homosexuality as a self-ascribed identity, developed by diagnosed "homosexuals" in reaction to their stigmatization. See E. Goffman, Stigma: Notes on the Management of Spolled Identrty 12-14 (1974) (members of stigmatized group may form militant "in-group" identities); K. PlUMmer, SEXUAL. STIGMA: AN INTERACTIONIST ACCOUNT 122-74 (1975) (applying Goffman's analysis to homosexuals in England).

Philippe Aries has suggested that the new concept, "homosexuality," achieved popular acceptance as social changes increased the expectations of emotional closeness in marriage, made married life more restrictive for men with sexual interest in other men, and reduced opportunities for extramarital sexual and emotional bonds between men. See Aries, Love in Married Life and The Indissoluble Marriage, in Western SEXUALITY, supra note 83, at 130-57. Aries' theory may also be used to explain the 19th-century emergence of "homosexuality" as a self-ascribed identity. If a married man has many other intense emotional involvements, and spends a considerable amount of time in a sexsegregated separate sphere, engaging in sexual activity with other men may pose no logistical or emotional problems for him; he may, therefore, do so without particularly noticing it or developing a homosexual identity. But if casual liaisons are less convenient, and marriage itself more emotionally demanding, married life may be less attractive or satisfactory for a man who is sexually attracted to other men. The resulting conflict could be resolved by such a man in several ways, including by adopting (subjectively, discovering) a homosexual identity. It is not surprising that Aries' theory does not explain the phenomenon of female homosexual identity particularly well; that emerged considerably later, see J. Lauritsen \& D. Thorstad, The Early Homosexual Rights Movement (1864-1935) 17-19 (1974), and for somewhat different reasons, see Rich, Compulsory Heterosexuality, in Powers of Desire: The Politics of Sexuality 177-205 (A. Snitow ed. 1983).

99. See, e.g., J. LauRITSEN \& D. Thorstad, supra note 98, at 9-45.

100. See Amicus Brief, supra note 84, at 8 (oral and anal sex are not harmful, but repression of sexual desires may cause dysfunction and pathology).

101. See american Psychiatric Association, Diagnostic and Statistical Manual of 
constitutes a normal variation is consistent with the nineteenth-century idea of homosexuality as an identity only in that both recognize the central part sexuality plays in life. The idea that homosexuality is normal, however, implies a recognition that homosexuality and heterosexuality may be not be rigidly distinct, mutually exclusive, categories. ${ }^{102}$ It is inconsistent with the nineteenth-century notion that "a homosexual" is fundamentally a different sort of person than "a heterosexual."

The various paradigms the Justices used to understand the act for which Hardwick was arrested shaped their responses to his assertion that he was protected by a constitutional right of privacy. The Justices who understood homosexuality to be immoral held it to be therefore utterly unlike the more conventional personal and family interests prior cases had protected, whereas the Justices who understood homosexuality to be normal analogized Hardwick's act to other forms of "intimate association." All of the Justices drew their conceptions of homosexuality from among paradigms current in contemporary society, although the majority's historical justification for its choice of meaning was deeply flawed. ${ }^{103}$

\section{Subtext and Text: The Political Philosophies UNDERLYING BOWERS v. HARDWICK}

The Justices' debate over the scope of constitutional "privacy" masked not only disagreement about the nature of Hardwick's activity, but also a dispute over fundamental values. Two competing political philosophies, classical conservatism and classical liberalism, respectively, underlie the Supreme Court majority and dissenting opinions. ${ }^{104}$ The Hardwick majority accepted Georgia's argument that even irrational popular prejudices should be enforced in order to preserve the very existence of society, because these prejudices may embody ancient wisdom. This argument resembles the classical conservatism of Edmund Burke and FitzJames Ste-

Mental Disorders 380 (3d ed. 1980); see also Amicus Brief, supra note 84, at 9-10 (describing history of adoption of this model).

102. "Homosexuality" is the exclusive preference of only a small percentage of those who, at some time in their adult lives, either experience sexual desire for, or participate in sexual acts with, persons of their own gender. See A. Kinsey, Sexual Behavior in the Human Male 650-51 (1948) (37\% of men have at least some overt homosexual experience to the point of orgasm between adolescence and old age; $10 \%$ are more or less exclusively homosexual for at least three years between the ages of 16 and 55); Plummer, Homosexual Categories, in The MAKing of The Modern HoMOSEXUAL 53-75 (1981).

103. See supra Section II-B-1.

104. I use the terms "conservative" and "liberal" with trepidation; these concepts have been used and redefined for so long and in so many ways that they have lost much of their meaning. See, e.g., H. Girvetz, The Evolution of Liberalism 23-26 (1963) (modified version of classical liberalism has become modern conservatism).

In this Comment, "classical conservatism" designates the constellation of values expressed by Edmund Burke and FitzJames Stephen, based on the view that the preservation of society in its present form is of preeminent value. "Classical liberalism" designates the constellation of values expressed by Jeremy Bentham and John Stuart Mill, based on the primacy of individual freedom. 
phen. ${ }^{105}$ Justice Blackmun's dissent implied that an individual's right to behave as he chooses may be limited only in order to prevent him from causing harm to others, a view reminiscent of the classical liberalism of Jeremy Bentham and John Stuart Mill. ${ }^{106}$ Disputes over similar issues in other contexts have been framed in these terms, most notably the extended written debate between Professor H.L.A. Hart ${ }^{107}$ and Lord Patrick Dev$\operatorname{lin}^{\mathbf{1 0 8}}$ when the Wolfenden Committee recommended in 1957 that criminal penalties for private and consensual sexual acts between men be repealed in Great Britain. ${ }^{109}$ Thus, the Supreme Court's discussion and resolution of Bowers $v$. Hardwick was shaped by thirty years of lively public, forensic, ${ }^{110}$ and scholarly ${ }^{111}$ debate about whether consensual lovemaking between two persons of the same sex ought to be a crime.

105. Compare E. Burke, Reflections on the Revolution in France 182-84 (C. O'Brien ed. 1969) (1st ed. 1790) (natural prejudices contain latent wisdom) and J.F. STEPHEN, LiBERTY, EQUAlity, Fraternity 157 (R. White ed. 1967) (2d ed. 1874) (fixed principles of society express accumulated wisdom of centuries) with 478 U.S. at 192-94 (White, J.) (emphasizing "ancient roots" of proscriptions against sodomy).

106. Compare J. Bentham, An Introduction to the Principles of Morals and LegislaTION 159 (Oxford ed. 1970) (1789) (punishment for otherwise disagreeable acts inappropriate if affected person consented) and J.S. MILL, ON LIBERTY 93 (E. Rapaport ed. 1978) (only prevention of harm to others justifies interfering with individual's liberty) with 478 U.S. at 199 (Blackmun, J., dissenting) ("[T]his case is about "the most comprehensive of rights and the right most valued by civilized men,' namely, 'the right to be let alone." ") (citation omitted).

107. H.L.A. HaRT, LAw, LiberTy and MORALrTy (1963). This book was augmented by several articles, including Immorality and Treason, The Listener, July 30,1959, at 162, reprinted in The LAW AS LITERATURE (L. Blom-Cooper ed. 1961) and Social Solidarity and the Enforcement of Morality, 35 U. Chr. L. REv. 1 (1967).

108. Lord Devlin collected his essays in one volume, The Enforcement of Morals. Both writers acknowledged that Lord Devlin's arguments were conservative and Professor Hart's, liberal. See P. Devlin, The ENForcement of MoRALS vi-vii (1965); H.L.A. HART, supra note 107, at 72-77; Williams, Authoritarian Morals and the Criminal Law, 1966 CRIM. L. Rev. 132.

109. The Wolfenden Report: Report of the Committee ON Homosexual Offenses and Prostitution II 62 (American ed. 1963) [hereinafter Wolfenden Report]. The Committee also defined "consenting," id. at II 63, "adult," id. at III 65-75, and "in private," id. at II 64 , and recommended penalties for those sexual acts it thought should remain crimes, id. at II 76-127.

British law was reformed as the Wolfenden Report had recommended by the Sexual Offenses Act, 1967 , ch. 60 .

110. Although the United States Supreme Court had never given plenary consideration to the question of whether consensual lovemaking between two adults of the same sex could be punished as a crime, several lower federal courts, and one state court, had done so. E.g., Baker v. Wade, 769 F.2d 289 (5th Gir. 1985) (law proscribing "deviate sexual intercourse with another individual of the same sex" held constitutional), cert. denied, 478 U.S. 1022 (1986); Doe v. Commonwealth's Attorney for Richmond, 403 F. Supp. 1199 (E.D. Va. 1975) (finding rational basis for sodomy law), affd mem., 425 U.S. 901 (1976); People v. Onofre, 51 N.Y.2d 476, 415 N.E.2d 936, 434 N.Y.S.2d 947 (1980) (law prohibiting consensual sodomy held unconstitutional).

111. The debate between Professor Hart and Lord Devlin spurred a considerable secondary literature. See, e.g., Dworkin, Lord Devlin and the Enforcement of Morals, 75 YALE L.J. 986 (1966); Hughes, Morals and the Criminal Law, 71 YALE L.J. 662 (1962).

In the United States, meanwhile, the Advisory Committee of the American Law Institute recommended that the Model Penal Code exclude consensual relations between adults from criminal punishment. See Model Penal. Code $\$ 20$ comments at 276 (Tentative Draft No. 4, 1955). The recommendation was initially rejected, but ultimately prevailed. See MOdel Penal Code § 213.2 (1964). This debate was also reflected in the law reviews. See, e.g., Cantor, Deviation and the Criminal Law, 55 J. CRIM. L., Criminology, \& Police ScI. 441 (1964); Hart, The Use and Abuse of the Criminal Law, Oxford LAw. Vol. 4, No. 1, 1961, at 7; Schwartz, Moral Offenses and the Model Penal Code, 63 Colum. L. Rev. 669 (1963). 


\section{A. The Hart-Deulin Debate}

The writings of H.L.A. Hart and Patrick Devlin provide a particularly instructive comparison with Bowers v. Hardwick because they consider the underlying philosophical questions raised by Hardwick with depth and rigor. Hart and Devlin debated the political philosophy which undergirded the Wolfenden Report's jurisprudential support for its substantive recommendations: the theory that protection of an individual from external harm was the only valid justification for criminal prohibitions; no other goal, and certainly no other moral theory, could be sufficient. ${ }^{112}$

Lord Devlin attacked one of the Wolfenden Report's key premises: that there is a realm of private morality that may not properly be enforced by the criminal law. ${ }^{113}$ Devlin argued that judgments about private morality must be made every day by sentencing judges, ${ }^{114}$ and are implicit in the mere proscription of some, although perhaps not all, crimes. ${ }^{115}$ Claiming that the Wolfenden Committee had conceded homosexuality to be morally wrong, Lord Devlin argued against a "freedom to be immoral,"116 because "[s]ociety is entitled by means of its laws to protect itself from dangers, whether from within or without."112 He thought the "viewpoint of the man in the street"118_especially when reflecting a visceral response ${ }^{119}$ - should be the only measure of both morality and danger to society. ${ }^{120}$ Although Lord Devlin conceded that the state might protect individual privacy from the criminal law by restricting methods of police investigation or by lenient sentences for private behavior, ${ }^{121}$ he argued

The development of the constitutional doctrine of privacy brought a renewal of the debate, now framed in constitutional terms. See, e.g., Henkin, Privacy and Autonomy, 74 Colum. L. REv. 1410 (1974); Karst, Freedom of Intimate Association, 89 YALE L.J. 624 (1980); Richards, Unnatural Acts and the Constitutional Right to Privacy, 45 Fordham L. REv. 1281 (1977); Note, Suspect Classification, supra note 29; Survey on the Constitutional Right to Privacy in the Context of Homosexual Activity, 40 U. MIAMI L. REv. 521 (1986).

112. Wolfenden Report, supra note 109 , II $13,14 \& 61$. This view derived from the liberalism of Bentham and Mill. See H.L.A. HART, supra note 107, at 13.

113. He was considerably more troubled by the Wolfenden Committee's rationales than by its recommendations. He conceded that homosexuality does society no tangible harm, P. DevLIN, Mill on Liberty in Morals, in THE ENFORCEMENT of Morals, supra note 108, at 102, 111-12, 116, and agreed that laws penalizing consensual adult homosexuality may themselves do society more harm than good, id. at 117.

114. P. Devlin, Morals and the Criminal Law, in The Enforcement of Morals, supra note 108 , at 1, 4 (for example, by treating an abortionist and an unlicensed midwife differently).

115. Id. at 5-7.

116. Id. at 8; $c f$. P. Devin, supra note 113, at 102, 121-22 (moral proscriptions are appropriate even if we are not sure proscribed conduct is evil).

117. P. Devin, supra note 114 , at 1 . Lord Devlin emphasized the danger of homosexuality by comparing it to treason. Id. at 13-14.

118. Id. at 15 .

119. Id. at 17 ("No society can do without intolerance, indignation and disgust; they are the forces behind the moral law, and indeed it can be argued that if they or something like them are not present, the feelings of society cannot be weighty enough to deprive the individual of freedom of choice.") (footnote omitted).

120. Id. at 17 (If society genuinely feels that homosexuality is "a vice so abominable that its mere presence is an offence . . . I do not see how society can be denied the right to eradicate it.").

121. Id. at 18-19; of. Bowers v. Hardwick, 478 U.S. at 197-98 (Powell, J., dissenting) (sug- 
that the community needed to be able to enforce the majority's moral views in order to preserve its own existence.

Lord Devlin's arguments were explicitly and self-consciously conservative. Indeed, he argued that basing the law upon rational considerations would be undemocratic and elitist. ${ }^{122} \mathrm{He}$ acknowledged that his argument that the law should enforce majoritarian morality was conservative, naming James FitzJames Stephen as his intellectual ancestor. ${ }^{123}$

Like Lord Devlin, Professor Hart was at least as interested in the Wolfenden Committee's jurisprudential theory as in its practical recommendations. ${ }^{124}$ His arguments therefore defended both John Stuart Mill and the Wolfenden Report, and attacked the theories of Edmund Burke and FitzJames Stephen along with those propounded by Lord Devlin himself. ${ }^{125}$ In defending the Wolfenden Committee's jurisprudence, Hart argued that although "we should attempt to adjust the severity of punishment to the moral gravity of offences," it does not follow "that punishment merely for immorality is justified." Hart explained that although "the only justification for having a system of punishment is to prevent harm and only harmful conduct should be punished," nevertheless using moral judgments to decide on the quantum of punishment for harmful conduct may support social morality and prevent the law from falling into disrepute. ${ }^{128}$ Pointing out that criminal laws affect both those persons actually punished under them and those persons "coerced into obedience by the threat of legal punishment," Hart argued that proscribing harmless sexual activities was particularly pernicious because of the "recurrent and insistent part" sexual impulses play in daily life: "[T]he suppression of sexual impulses generally is[] something which affects the development or balance of the individual's emotional life, happiness, and personality." ${ }^{27}$ Professor Hart characterized Lord Devlin's argument that society must enforce majoritarian morality to protect itself as "a highly ambitious empirical generalization" for which Devlin had offered neither evidence nor even any "indication ... of the kind of evidence that would support

gesting that homosexual lovemaking may be made a crime, but not punished too severely).

122. See P. Devlin, Democracy and Morality, in The Enforcement of Morals, supra note 108 , at $86,91-97$ (arguing that, in a democracy, morals should be decided by the majority, just as other policy choices are).

123. P. Devlin, Morals and Contemporary Social Reality, in The Enforcement of Morals, supra note 108, at 124, 126-28; $f$. J.F. STEPHEN, supra note 105, at 152 ("[T] and the desire of vengeance [that the grosser forms of vice excite in healthily constituted minds] are important elements of human nature which ought in such cases to be satisfied in a regular public and legal manner.").

124. See, e.g., H.L.A. HART, supra note 107, at 14.

125. See, e.g., id. at 48-52 (arguing against Devlin's "moderate thesis" and Stephen's "extreme thesis"); id. at 73-77 (discussing whether Burke's "evolutionary defence of tradition and custom" supports Devlin's position).

126. Id. at 36-37 (emphasis in original). Lord Devlin rejected Professor Hart's distinction between rationales for sentencing and for the prohibitions themselves as spurious. See P. DEVLIN, supra note 123 , at $124,129-31$.

127. H.L.A. HART, supra note 107, at 21-22. 
it." ${ }^{128}$ Professor Hart acknowledged that it might be possible to discriminate empirically between those portions of society's moral code necessary for social existence and those that were superfluous, but noted that it would be difficult to do so. ${ }^{128}$ Until empirical evidence demonstrating the necessity for any particular moral rule was available, Hart concluded, Lord Devlin's arguments rested entirely upon the "conservative thesis" that "the majority have the right to enforce its . . . convictions that their moral environment is a thing of value to be defended from change."130

One of Lord Devlin's most enduring contributions to the debate about the role of morality in the criminal law was his development of a list of existing crimes which he used to challenge the liberal argument that "private immorality should altogether and always be immune from interference by the law." ${ }^{\text {"181 }}$ This list included: treason, ${ }^{132}$ euthanasia or the killing of another at his own request, suicide, attempted suicide and suicide pacts, dueling, abortion, incest between brother and sister, gambling, drunkenness, living on the earnings of a prostitute, bestiality, conspiracy to corrupt morals, bigamy, and polygamy. ${ }^{133}$ Some version of Lord Devlin's list has become a staple in arguments over whether private lovemaking between consenting adults should be legal, ${ }^{134}$ and a version of it appears in Bowers v. Hardwick. ${ }^{135}$

Professor Hart responded to Devlin's list in two ways. First, he argued that " the actual existence of laws of any given kind is wholly irrelevant to [the] contention . . . that it would be better if laws of such a kind did

\footnotetext{
128. Hart, Social Solidarity, supra note 107, at 3. As Professor Hart recognized:

[I]f we mean by "society ceasing to exist" not "disintegration" nor "the drifting apart" of its members, but a radical change in its common morality, then the case for using the law to preserve morality must rest not on any disintegration thesis but on some variant of the claim that when groups of men have developed a common form of life rich enough to include a common morality, this is something which ought to be preserved. One very obvious form of this claim is the conservative thesis that the majority have a right in these circumstances to defend their existing moral environment from change. But this is no longer an empirical claim.

Id. at 4 (emphasis in original).
}

129. Id. at $8-13$.

130. Id. at 2,13 .

131. P. Devur, Mill on Liberty in Morals, supra note 113, at 102, 110

132. See supra note 117.

133. See P. Devlin, supra note 108, at 14, 107, 113, 128. Although J. FitzJames Stephen had claimed that "English criminal law does recognize morality" because "a considerable number of acts which need not be specified are treated as crimes merely because they are regarded as grossly immoral," J.F. STEPHEN, supra note 105, at 154 (footnote omitted), I believe Lord Devlin was the first to compile a list of existing crimes to demonstrate the point.

134. See, e.g., Caron, The Legal Enforcement of Morals and the So-Called Hart-Devlin Controversy, 15 MCGILL L.J. 9 (1969) (discussing homosexual acts by comparison with incest, euthanasia, murder consented to by the victim, attempted suicide, dueling, suicide pacts, and abortion); Hughes, supra note 111, at 669-72 (criticizing Devlin's use of list); Williams, supra note 108 (discussing Devlin's jurisprudence).

135. In the course of rejecting Hardwick's argument that, under Stanley v. Georgia, 394 U.S. 557 (1969), "homosexual contact [which] occurs in the privacy of the home" is constitutionally protected, 478 U.S. at 195-96. Justice White compared homosexual sodomy with "[v]ictimless crimes, such as the possession and use of illegal drugs[,] . . possession in the home of drugs, firearms, or stolen goods[,] . . . adultery, incest, and other sexual crimes . . . " 478 U.S. at 195-96. 
not exist." "136 Second, he attempted to show that many of the crimes on Lord Devlin's list were not solely attempts to enforce morality. ${ }^{137}$

\section{B. Bowers v. Hardwick Recasts the Hart-Devlin Debate}

In many respects, Bowers v. Hardwick recast the Hart-Devlin debate in constitutional terms. ${ }^{138}$ Understanding White's majoritarian justifications for seeing "homosexual sodomy" as immoral, and Blackmun's responses to it, is key to understanding the philosophical similarities between Bowers v. Hardwick and the Hart-Devlin debate. Like Lord Devlin, Justice White ${ }^{\mathbf{1 3 9}}$ and Chief Justice Burger ${ }^{\mathbf{1 4 0}}$ defended the criminal proscription of homosexual lovemaking by appealing to tradition and morality. Like Professor Hart, Justices Blackmun ${ }^{141}$ and Stevens ${ }^{142}$ would have required proof that private homosexual lovemaking was harmful before permitting the state to proscribe it. These differences reflect, respectively, the conservative position, for which the desirability of protecting society's existing form is unquestioned, and the liberal position, for which individual liberty is the primary value. Liberal values and conservative values are incommensurable. Although one can make an intelligible choice between them, this cannot be done from an Archimedean perspective.

In addition to his misleading historical claims, White relied on "the presumed belief of a majority of the Georgia electorate that homosexual sodomy is immoral and unacceptable."143 Although careful analysis suggests that White was working within the conservative perspective, his majoritarian justification can be interpreted in both conservative and liberal ways. The conservative interpretation assumes that White agreed with Fitzjames Stephen and Lord Patrick Devlin that strongly held popular prejudices are by themselves sufficient justification for criminal proscriptions. The liberal interpretation assumes that White accepted Jeremy Bentham's principle that criminal proscriptions must be limited to curbing behavior causing harm to others. Many of the dissenters' arguments, and almost all of the scholarly commentary, have been written from within the liberal perspective, and assume White to have been asserting that homosexuality is harmful. ${ }^{144}$ Yet White's argument fails in liberal terms, since

136. H.L.A. HART, supra note 107, at 28 (quoting J. Morley) (footnote omitted).

137. Id. at 25-52.

138. Of course Hardwick was an exercise in Constitutional interpretation, whereas the HartDevlin debate addressed a policy question for a legislature unchecked by a written constitution. Nevertheless, when the Court interprets such "open textured" terms as "Due Process," "privacy," and "fundamental rights," it is forced to resort to what are essentially policy arguments. See H.L.A. HaRT, The Concept of LAw 121-32 (1961).

139. See 478 U.S. at 191-94.

140. See id. at 196-97 (Burger, C.J., concurring).

141. See id. at 208-09 (Blackmun, J., dissenting).

142. See id. at 217 (Stevens, J., dissenting).

143. Id. at 196.

144. See, e.g., Conkle, supra note 7, at 233-34 (Georgia's interest in enforcing morality inter- 
he never attempts to identify any harm caused by consensual adult sodomy. ${ }^{145}$

In conservative terms, however, White's argument is coherent. When he relied on "the presumed belief of a majority of the Georgia electorate," White meant that Georgia might proscribe homosexuality solely because it was abhorred by the majority. When he compiled a list strikingly similar to Lord Devlin's by comparing "homosexual sodomy" to "[v]ictimless crimes, such as the possession and use of illegal drugs[,] . . possession in the home of drugs, firearms, or stolen goods[,] . . . adultery, incest, and other sexual crimes," 146 White, like Devlin, was arguing that society often legislates on the basis of morality alone, and that this is entirely proper.

Blackmun explicitly repudiated White's conservative premises at some points, ${ }^{147}$ but at others merely implicitly assumed the primacy of liberal values. Although, as just argued, Justice White's opinion is more coherent when understood in conservative terms, Justice Blackmun sometimes interpreted it as a liberal argument. Treating White's use of his Devlin-like list as shorthand for the liberal argument that all these crimes cause harm, Blackmun retorted that private, consensual, violations of Georgia's law were obviously neither the cause nor the effect of harm to any individual. ${ }^{148}$ Blackmun's implicit assertion that the crimes on White's list are proscribed because they harm identifiable individuals may be correct for most of the crimes. Adultery ${ }^{\mathbf{1 4 9}}$ and sexual crimes involving the use of actual or constructive force ${ }^{150}$ may be distinguished from "homosexual

preted as protecting either homosexuals or other citizens from harm); Gillerman, supra note 7, at 6 (criticizing equation of homosexuality with moral corruption because such equation "lacks empirical foundation"); Richards, supra note 7, at 859-60 (because homosexuality is not harmful, treating it differently from other nonprocreative sexuality is unjust); Leading Cases, supra note 7, at 219 (Court should have required "an independent rational basis" for Georgia's law, "something more than the moral choice of a majority").

145. Within the liberal paradigm, any defense of Georgia's law must be on the basis that "homosexual sodomy" causes some sort of harm, and therefore, since the Georgia electorate had determined homosexuality to be harmful to society, it was justified in proscribing it. Cf. P. Devlin, supra note 114 , at $1,9-14$ (society may use the criminal law to preserve morality in order to safeguard its own existence). This argument has been convincingly refuted by Ronald Dworkin. See R. DworkIN, TAKING RIGHTS SERIOUSLy 242 (1978) (noting that public outrage alone does not indicate that given prohibition is necessary to society's continuation); see also 478 U.S. at 210-12 (Blackmun, J. dissenting) (making same point).

146. 478 U.S. at $195-96$.

147. Blackmun attacked conservative premises directly when he wrote, "Like Justice Holmes, I believe that "[i]t is revolting to have no better reason for a rule of law than that so it was laid down in the time of Henry IV, " 478 U.S. at 199 (Blackmun, J., dissenting) (citing Holmes, The Path of the Law, 10 HARv. L. REv. 457, 469 (1897)), and, "I cannot agree that either the length of time a majority has held its convictions or the passions with which it defends them can withdraw legislation from this Court's scrutiny." 478 U.S. at 210 (Blackmun, J., dissenting).

148. Id. at 208-09. Like Justice Blackmun, Professor Hart responded to the list from within the framework of liberal values, arguing that the state's ability to enforce some morality can give it the power to prohibit homosexual acts only if some matter of appropriate state concern is linked to the specific prohibition. Hart, Social Solidarity, supra note 107, at 9 n.21.

149. 478 U.S. at 209 n.4 (Blackmun, J., dissenting) (state may punish adultery as breach of promise to be faithful, or because it harms third parties).

150. Such crimes include rape, forcible sodomy, statutory rape, child molestation, and incest be- 
sodomy" on this basis. Yet incest between adults ${ }^{151}$ is not clearly harmful. ${ }^{152}$

Blackmun's own liberal assumptions prevented him from recognizing that White's use of the list was shorthand for the conservative argument that the criminal law may properly be used "to preserve order and decency."163 Professor Hart responded to this argument by requesting empirical evidence of the necessity for any criminal prohibition based upon morality; had Blackmun done so, his rhetorical position would have been stronger. Instead, Justice Blackmun attempted to refute the majority's argument on liberal terms by seeking to distinguish homosexual love from incest between adults. He may have tried to do so in order to contain the anarchic risks implied by a rule favoring individual sexual freedom. ${ }^{154}$ Yet he set himself a formidable task, because incest between adults seems not to cause any discernable harm to an identifiable individual.

The dissenters' most creative responses to the majority pushed beyond the Hart-Devlin debate, turning the conservative argument against itself. Instead of accepting the assertion that homosexuality is universally considered immoral, as Hart implicitly did, Stevens denied that homosexuality is abhorred even in Georgia. ${ }^{155}$ Blackmun did not challenge this factual premise. Recalling that the values of pluralistic diversity and individual liberty form a traditional part of our society's morality, he paradoxically asserted that these liberal values should be considered paramount in constitutional interpretation, even by those who consider conserving our society in its present form a primary value. ${ }^{188}$

\section{Political Philosophy and Constitutional Privacy}

Commentators have found it difficult to explain how Michael Hardwick's challenge to a law proscribing private lovemaking between consenting adults could have failed. One suggested that the case heralds a

tween a child and an adult.

151. At oral argument, the Court expressed particular concern with the states' continuing ability to proscribe a sexual relationship between adults who are within prohibited degrees of consanguinity or affinity. See Transcript of Oral Argument at 22, Bowers v. Hardwick, 478 U.S. 186 (1986) (No. 85-140) [hereinafter Oral Argument].

152. Blackmun's argument that incest is "inherently coercive" is anomalous: If structural inequality between two people makes their lovemaking "sufficiently problematical that a blanket prohibition .. . is warranted," 478 U.S. at 209 n.4 (Blackmun, J., dissenting), all heterosexual lovemaking should also be prohibited.

153. See P. Devin, supra note 114, at 1,$7 ;$;f. 478 U.S. at 196 ("The law . . is constantly based on notions of morality.").

154. See infra text accompanying note 161 .

155. 478 U.S. at 219-20 (Stevens, J., dissenting).

156. 478 U.S. at 205 (Blackmun, J., dissenting) (" $[I] n$ a Nation as diverse as ours . . . there may be many right ways of conducting [intimate sexual] relationships"); id. at 203 (" 'Our cases have long recognized that the Constitution embodies a promise that a certain private sphere of individual liberty will be kept largely beyond the reach of government." ") (quoting Thornburgh v. American College of Obstetrics \& Gynecology, 476 U.S. 747, 772 (1986)). 
"second death of substantive due process",is7 another called it "one of the most transparently unprincipled exercises of judicial power in recent years." ${ }^{158}$ Hardwick's case could hardly have been stronger. He was arrested in his own home; the Georgia statute applied equally to homosexual and heterosexual lovers, whether married or single, and its nonenforcement was even-handed. Hardwick's complaint invoked his "right of privacy," reminding the Court that it had already vindicated the rights of married women to get abortions over their husbands' objections, ${ }^{159}$ and of children to birth control. ${ }^{160}$ Yet he lost.

This Comment has offered an alternative interpretation of why Hardwick lost an apparently straightforward case. It has shown how Bowers $v$. Hardwick reflects a battle between two incommensurable and incompatible systems of fundamental values: classical liberalism and classical conservatism.

Both liberal and conservative philosophies make single goals the touchstone of their analysis. Individual freedom is of paramount value for classical liberalism, and the continued existence of society in its present form is of paramount value for classical conservatism. However useful this technique may be for philosophical analysis, risks inhere in using either value as a rationale for deciding cases. These risks are most clearly perceived from the opposing perspective. The risks of the extreme liberal position are risks to conservative values. Taken to its logical limit, the liberal argument seems to risk anarchy, since a totally unfettered right to be left alone might undermine virtually all social control over individuals. ${ }^{161}$ Similarly, the risks of the extreme conservative position are risks to liberal values. At its logical limit, the conservative argument degenerates into "mere moral conservatism,"162 preserving even manifest injustice and tyranny from change by preventing normative criticism of traditional laws. ${ }^{163}$

The disagreements between the majority and dissenting Justices in Hardwick demonstrate the uneasy balancing of risk characteristic of judicial decisions where these polar values clash. ${ }^{164}$ The resolution of any dis-

157. Conkle, supra note 7 , at 215.

158. Richards, supra note 7 , at 800 .

159. Planned Parenthood v. Danforth, 428 U.S. 52 (1976).

160. Carey v. Population Services Int'l, 431 U.S. 678 (1977).

161. See, e.g., Gavison, Privacy and the Limits of the Law, 89 YALE L.J. 421, 437-38 (1980) ("right to be let alone" would prevent tax collection and conscription); Punzo, Morality and the Law: The Search for Privacy in Community, 18 ST. Louss U.L.J. 175, 186, 191-93 (1973) (if individual may freely engage in activities that directly affect only his own life, state may not enforce laws against homosexuality, gambling, prostitution, pornography, polygamy, polyandry and drug use).

162. H.L.A. HART, supra note 107 , at 72 .

163. See Hart, supra note 111 , at 12 (In a society "whose principal occupation is torturing a racial minority ... . surely the argument that certain laws are required to preserve the society is not per se sufficient to justify the misery they cause."); cf. 478 U.S. at 210 n.5 (Blackmun, J., dissenting) (discussing parallels between anti-sodomy laws and anti-miscegenation laws).

164. Blackmun's paradoxical claim that valuing individual liberty is one of our hallowed traditions was an attempt to shift the terms of this debate. 
pute pitting liberty against tradition requires a balance between potential anarchy and potential tyranny. A court's assessment of the potential risk of any result must therefore depend heavily on how the facts are construed. In Hardwick, each Justice's calculation of the relative dangers of a liberal or a conservative decision was determined by his or her understanding of the act for which Hardwick was arrested.

If homosexuality is intrinsically immoral, as Justice White and Chief Justice Burger implicitly asserted, a liberal decision might well be the more dangerous. Depriving the state of the power to arrest and punish an adult for engaging in intrinsically immoral behavior might undermine its power to curb other traditionally disfavored but private and consensual practices, such as suicide, drug use, adultery, and incest. The risk of a liberal decision could then be discussed in terms of a need for a limiting principle, ${ }^{\mathbf{1 6 5}}$ an answer to the question, "Where will it end?"

If homosexuality is a normal variation, however, as the dissenters implicitly asserted, a conservative decision might easily be the more dangerous. If homosexual love is as normal as any other, a conservative decision risks government enforcement of a majority's intolerance in other sensitive areas of life as well. The relevant comparisons are then not between homosexuality and incest or suicide, but between homophobia and religious intolerance or racial animus. ${ }^{186}$ If a state may proscribe and punish a "sensitive, key relationship of human existence" such as sexual love, few limits remain on its control of individual autonomy, and on its imposition of majority preferences upon minorities with other values. ${ }^{167}$

The Justices' assessment of the risk inherent in the classical liberal and conservative resolutions of this case in turn determined how they applied the doctrine of constitutional privacy to the facts of Hardwick. The Court's prior decisions invoking constitutional privacy may be interpreted in both liberal and conservative terms. One liberal interpretation of "privacy" is as "autonomy." This concept is fully consistent with the classical liberal view that individual liberty is a primary value. ${ }^{168}$ In contrast, one conservative interpretation of privacy is that it guarantees no more than "seclusion" for otherwise legal activities. ${ }^{169}$ This view is consistent with

165. See Oral Argument, supra note 151, at 18-19 (questions by Justice Powell); id., 21-22 (question by Chief Justice Burger).

166. See 478 U.S. at 211-12 (Blackmun, J., dissenting); id. at 219 (Stevens, J., dissenting).

167. See Conkle, supra note 7 , at 215 .

168. See, e.g., Cleveland Bd. of Educ. v. LaFleur, 414 U.S. 632, 639 (1974) ("freedom of personal choice in matters of marriage and family life"); Eisenstadt v. Baird, 405 U.S. 438 (1972) (individual's right to decide whether to bear or beget child); see also Henkin, supra note 111 (interpreting constitutional "privacy" as autonomy by reference to Enlightenment philosophy); Karst, supra note 111 (interpreting privacy cases as protecting autonomy); Punzo, supra note 161 (deriving definition of privacy as autonomy from premise that individual freedom is of paramount importance).

169. See Posner, The Uncertain Protection of Privacy by the Supreme Court, 1979 SUP. CT. Rev. 173, 193 (privacy as seclusion); cf. Stanley v. Georgia, 394 U.S. 557 (1969) (right to possess obscene matter in seclusion of home). 
making society's unchanged continuation a primary value. Interpreting privacy as protection only for traditional relationships ${ }^{170}$ is conservative for the same reason. ${ }^{171}$ In Hardwick, the Justices in the majority neither explained which of these definitions of privacy they were invoking, nor articulated the understandings of homosexuality they held before they compared Hardwick's actions with the facts of prior cases. ${ }^{172}$ This silence obscured the underlying determinants of their opinions.

In the Hart-Devlin debate, once both sides had articulated their positions fully, it became clear that their disagreements were over fundamentally distinct and incommensurable normative frameworks, and therefore that the debate was incapable of resolution by reasoned argument. In Bowers v. Hardwick, however, conservatism appears to have won along with the state of Georgia. On the basis of profoundly conservative arguments the case denied constitutional protection to a politically weak minority woefully in need of equal treatment. ${ }^{178}$ The decision's potential for undermining the entire liberal privacy doctrine ${ }^{174}$ is greatest if homosexuality is understood as a normal variation, because Hardwick then implies that a state may proscribe any intimate relationship or decision. Future litigants will therefore experience a strong temptation to limit the decision's precedential effect by distinguishing themselves from homosexuals, perhaps even on the basis that homosexuality has "always been abhorred." Seen in this way, the case is an impressive victory for conservative values. It may shift the argument about whether an activity is protected by the constitutional right of privacy from the liberal paradigm, where individual liberty is protected unless it sufficiently endangers society, to the conservative paradigm, where state restrictions are upheld so long as they are sufficiently consistent with "traditional values."

Nevertheless, scoring the winners and losers in this case is really not so simple. The probable effects of this decision are both complex and paradoxical. In some respects, conservatism lost as well. The "presumed belief

170. See, e.g., Zablocki v. Redhail, 434 U.S. 374, 386 (1978) (right to remarry because marriage is foundation of family); Moore v. Gity of East Cleveland, 431 U.S. 494, 504 (1977) (extended family protected because it is as venerable as nuclear family); Loving v. Virginia, 388 U.S. 1, 12 (1967) (marriage basic civil right because it has long been recognized as essential to happiness).

171. At least two related intermediate positions have been identified. One refers to an individual's ability to limit others' access to himself or herself. See Gavison, supra note 161 (limits on access to self). The other refers to an individual's ability to limit others' access to information about him or her. See Fried, Privacy, 77 YALE L.J. 475 (1968) (limits on access to personal information). Both are equally consistent with liberal and conservative values, and derive from Fourth Amendment cases. See, e.g., Boyd v. United States, 116 U.S. 616 (1886) (limits on production of private papers).

172. See 478 U.S. at $190-92$.

173. See, e.g., Dressler, Judicial Homophobia: Gay Rights Biggest Roadblock, 5 Civ. Lib. Rev. No. 4, 19, 21 (Jan./Feb. 1979); Rivera, Queer Law: Sexual Orientation Law in the Mid-Eighties Part II, 11 U. Dayton L. Rev. 275 (1986); Rivera, Queer Law: Sexual Orientation Law in the Mid-Eighties Part I, 10 U. Dayton L. Rev. 459 (1985); Rivera, Recent Developments in Sexual Preference Law, 30 Drake L. REv. 311 (1980-81); Rivera, Our Straight-Laced Judges: The Legal Position of Homosexual Persons in the United States, 30 Hastings L.J. 799 (1979).

174. See supra notes $166-72$ and accompanying text. 
of a majority of the electorate in Georgia"175 is no more than shorthand for a circular argument: The statute was justified by reliance on popular morality. But popular morality itself was supposedly evidenced by the statute's mere existence. Seen in this way, the decision is a defeat for the conservative principle of deference to majoritarian values. Contrary to their protestations, the Justices of the Hardwick majority ignored the explicit language of Georgia's law and the actual conduct of its law enforcement officers in order to impose their own values ${ }^{176}$ on the states under a cloak of historical invention. ${ }^{177}$

This case may have been a defeat for conservative values in another sense as well. In A History of the Criminal Law of England, FitzJames Stephen implied that criminal laws could be adequately justified by strong popular prejudice because a prejudiced majority might otherwise use mob violence to enforce its views. ${ }^{178}$ These ideas were perhaps sound in Stephen's place and time, but the United States in the latter half of the twentieth century is a pluralistic mixture of cultures and values. In our country, and our century, it is not at all clear that domestic peace is advanced when a majority imposes its values on the rest of society. Justice Blackmun put it well: In a pluralistic society, attempting to compel adherence to one set of values and beliefs may well constitute a greater threat to "national cohesion"179 than mere pluralism ever could be.

\section{Conclusion}

Although Bowers v. Hardwick appears to be an incremental step in the Court's exegesis of its privacy doctrine based on fact and history, the opinions really turn on the Justices' unstated disagreements over fundamental political values. The majority applied classical conservative principles, permitting Georgia to justify its statute by its congruence with traditional moral views. It grounded this argument in the Constitution by equating "tradition" with the views of the Founders. The dissenters challenged the majority on two levels: Blackmun accepted the factual premise that homosexuality was abhorred when the Constitution was adopted, but rejected the notion that this is constitutionally significant, and Stevens challenged this factual premise itself. As both Hardwick and the Hart-Devlin debate show, the dispute between classical liberalism and classical conservatism cannot be resolved by resort to a meta-ethical methodology. What is clear

175. 478 U.S. at 196.

176. Justice Blackmun intimated that the majority's decision was based upon prejudice. 478 U.S. at $211-12$ (Blackmun, J., dissenting).

177. Cf. 478 U.S. at 192-94.

178. 2 J.F. Stephen, A History of the Criminal Law of England 82 (1883) (criminal sanctions control expression of public hatred of crime as marriage controls sexual passions); accord J.F. Stephen, supra note 105, at 124 (if criminal law did not deal with an association of seducers, "lynch law" would).

179. 478 U.S. at 214 (Blackmun, J., dissenting). 
in Hardwick, however, as Stevens noted, is that the majority's historical claims were inaccurate. Its attempt to ground its holding in American and Western history must be judged a failure.

If the majority had understood the history of sodomy statutes, it would have found it harder to limit its consideration of the Georgia statute to its effects upon a politically weak minority. ${ }^{180}$ An accurate assessment of the 1791 and 1868 statutes would have made the implications of the Court's method much plainer. If the framers' values are represented by these statutes, then "sodomy" between a man and a woman, even within marriage, has no more protection than sodomy between two men. By mischaracterizing history and misunderstanding "homosexuality," the majority was able to make a profound change in constitutional interpretation, from the liberal to the conservative paradigm, without acknowledging either that it had done so or the implications of this shift.

180. The Court explicitly reserved consideration of the constitutionality of the Georgia statute as applied to "acts of sodomy" between parties other than homosexuals. 478 U.S. at 188 n.2. Yet given that heterosexual sodomy, including sodomy in marriage, was also proscribed in 1791 and 1868, it is difficult to see how the majority's historical method of constitutional interpretation could produce any result other than finding heterosexual sodomy constitutionally unprotected. 


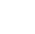

